


\section{Observations on the Biology of Rodents in Uruguay}
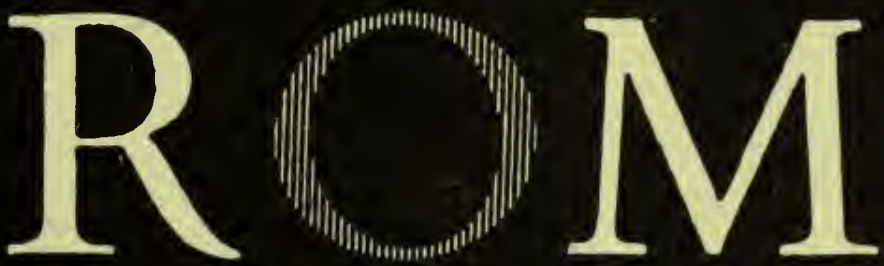

LIFE SCIENCES CONTRIBUTIONS

ROYAL ONTARIO MUSEUM

NUMBER 75

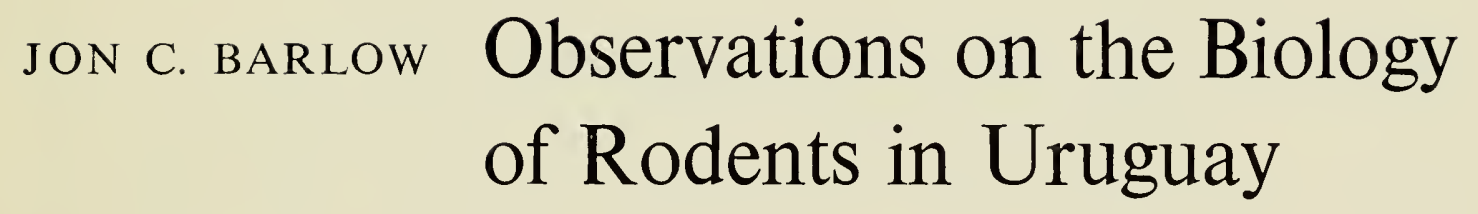

Publication date: 30 December 1969

Suggested citation: Life Sci. Contr., R. Ont. Mus. 


\section{ROYAL ONTARIO MUSEUM \\ PUBLICATIONS IN LIFE SCIENCES}

The Royal Ontario Museum publishes three series in the Life Sciences:

LIFE SCIENCES CONTRIBUTIONS, a numbered series of original scientific publications, including monographic works.

LIFE SCIENCES OCCASIONAL PAPERS, a numbered series of original scientific publications, primarily short and usually of taxonomic significance.

LIFE SCIENCES MISCELLANEOUS PUBLICATIONS, an unnumbered series of publications of varied subject matter and format.

All manuscripts considered for publication are subject to the scrutiny and editorial policies of the Life Sciences Editorial Board, and to review by persons outside the Museum staff who are authorities in the particular field involved.

LIFE SCIENCES EDITORIAL BOARD, 1969

Chairman: P. C. SWANN

Director, Royal Ontario Museum

Editors: G. B. WIGGINS

R. L. PETERSON

JON C. BARLOW is Curator of the Department of Ornithology, Royal Ontario Museum, and Associate Professor of Zoology, University of Toronto.

PRICE： $\$ 2.50$

(C)The Royal Ontario Museum, 1969

100 Queen's Park, Toronto, Canada

PRINTED BY THE HUNTER ROSE COMPANY 


\section{Contents}

Acknowledgments, 1

Abstract, 3

Introduction, 4

Methods, 5

Species Accounts, 9

Oryzomys delticola Thomas, 10

Oryzomys flavescens (Waterhouse), 14

Thomasomys oenax Thomas, 16

Akodon azarae azarae (Fischer), 18

Akodon obscurus obscurus (Waterhouse), 22

Oxymycterus rufus nasutus (Waterhouse), 24

Scapteromys tumidus (Waterhouse), 27

Calomys laucha laucha (Desmarest), 34

Reithrodon physodes physodes Olfers, 35

Holochilus brasiliensis vulpinus (Brants), 39

Holochilus magnus Hershkovitz, 41

Mus musculus ssp. Linnaeus, 42

Cavia pamparum Thomas, 43

Hydrochoerus hydrochaeris uruguayensis (C. Ameghino and Rovereto), 44

Myocastor coypus bonariensis (Commerson), 47

Ctenomys torquatus Lichtenstein, 48

Concluding Remarks, 55

Literature Cited, 57 
Digitized by the Internet Archive in 2011 with funding from University of Toronto 


\section{Acknowledgments}

Many people have contributed in a variety of ways to the preparation of this report. Dr. Richard G. Van Gelder (Chairman and Associate Curator of Mammalogy) and Dr. Sydney Anderson (Associate Curator of Mammalogy) of the American Museum of Natural History most kindly made possible my participation in the expedition to Uruguay whence came the field data and also made available to me the facilities of the Department of Mammalogy in the course of the laboratory research. Comments and suggestions were made in the field by these men and by Dr. Karl F. Koopman (Associate Curator of Mammalogy), also of the American Museum.

In Uruguay I also received help from John K. Bouseman, Thomas J. McIntyre, Merlin D. Tuttle, Sr. Armando J. Tocchéton (Sã̃ Paulo, Brazil), and especially from Sr. Alfredo Langguth and Sr. Alfredo Ximénez, mammalogists from the Museo de Historia Natural of Montevideo (all of whom participated in the field work). Later Sr. Langguth sent me additional data pertaining to the ecology of certain rodents. Other personnel from the Museum in Montevideo generously providing assistance were Sr. Juan Cuello, Sr. Miguel Klappenbach, Sr. Martin Mowszowicz, Sr. Braulio Orejas and Sr. Juan Uraga. I am indebted to Don Diego Legrand and especially to Sr. Richardo Praderi for identification of the plants that I collected. Dr. Fernando Mañé-Garzón identified certain ectoparasites. Sr. Eduardo Wilson assisted in the field in Durazno as did officers and members of the Centro de Estudias de Ciencias Naturales of Montevideo.

The present report is based on part of a doctoral dissertation submitted to the Department of Zoology and the Faculty of the Graduate School of the University of Kansas. I am most grateful to Dr. Richard F. Johnston, my graduate advisor at the University of Kansas who guided the doctoral research and to Professors William M. Bass and William A. Clemens (the latter now of the University of California at Berkeley) who critically read the original manuscript.

John E. Ubelaker identified nematodes and Professor George W. Byers of the Snow Entomological Museum of the University of Kansas identified insect remains from mammal stomachs. Others at Kansas who gave much appreciated help include: Mrs. Elsa Bardack, J. F. Downhower, Mrs. John Glinka, B. L. Keller, T. E. Lawlor and A. L. Metcalf.

For critical reading of various versions and parts of the present manuscript I am grateful to Sydney Anderson (American Museum), Philip Hershkovitz (Field Museum), Karl F. Koopman (American Museum), Randolph L. Peterson (Royal Ontario Museum), Dennis M. Power (Royal Ontario Museum) and J. R. Tamsitt (Royal Ontario Museum).

I thank also Mrs. C. Goodwin, Mrs. S. Poray, and Leighton Warren, all of the Rom, for help in production of the plates, and Mrs. S. Dugdale and Miss E. Woo who typed the final drafts of the manuscript. I am grateful to my wife, Judith, for help in typing earlier parts of this report and more especially for moral support and patience throughout the course of study. 
For financial assistance, I am indebted to the United States Army Medical Research and Development Command which provided support for the expedition under the auspices of Grant No. DA-MD-49-193-63-G82 to the Department of Mammalogy of the American Museum. In the spring of 1964, the University of Kansas awarded me a travel grant enabling me to visit the American Museum to examine specimens during a critical part of the study. 


\title{
Observations on the Biology of Rodents in Uruguay
}

\begin{abstract}
An expedition from the American Museum of Natural History visited the South American Republic of Uruguay between December 1962 and the end of May 1963, to collect mammals and their ectoparasites. More than 630 specimens comprising 16 species of rodents-Oryzomys delticola, O. flavescens, Thomasomys oenax, Akodon azarae, A. obscurus, Oxymycterus nasutus, Scapteromys tumidus, Calomys laucha, Reithrodon physodes, Holochilus brasiliensis, H. magnus, Mus musculus, Cavia pamparum, Hydrochoerus hydrochaeris, Myocastor coypus and Ctenomys torquatus-were collected in woodland, grassland and limnic habitats.

In the present report data on distribution, abundance, habitat preferences, food habits, breeding and moult are presented for most species of rodents collected. Oryzomys delticola was common and favoured woodland and ecotonal situations throughout the country. The rare Thomasomys oenax was found only in the dense subtropical forest of deep canyons in the north. Oryzomys flavescens, Akodon sp., Oxymycterus, Scapteromys, and Holochilus brasiliensis were fairly common principally in and near limnic habitats which predominated especially in the southern half of the country. Holochilus magnus, Myocastor coypus and Hydrochoerus hydrochaeris were less common than the above but also were found in limnic situations. The fossorial hystrichomorph Ctenomys torquatus and the mice Calomys laucha and Reithrodon physodes preferred grassland. The former species was common and the latter pair uncommon. The only Mus musculus taken came from a granary and beneath corn shocks.

Akodon sp., Oxymycterus and Scapteromys fed largely on invertebrates. All other native species mentioned in this report were predominantly herbivorous.

Evidence of current breeding activities were found in the cricetines and Cavia. All demonstrated apparent reproductive peaks in early summer (December) and mid-autumn (late April to mid-May). The only other species obtained in good numbers, Ctenomys torquatus, was not found to be in breeding condition in the course of our field work, but is known to give birth to young in early spring.

Ctenomys torquatus demonstrated evidence of a post-breeding autumnal moult. In cricetines and Cavia pamparum moult was more or less continuous with peaks in mid-summer and late autumn.
\end{abstract}




\section{Introduction}

Much remains to be learned about the ecology and distribution of mammals in the countries of South America. The mammalian fauna of Uruguay has proved no exception in this regard. The present report deals with aspects of the biology of 16 species of rodents represented by more than 630 specimens collected in Uruguay primarily between early December 1962 and the end of May 1963 by members of an expedition from the Department of Mammalogy of the American Museum of Natural History.

The first collecting and recording of significant observations of animals in Uruguay are attributable to the British naturalist, William Toller. Toller mentions the capybara (Hydrochoerus hydrochaeris) in the account of his visit in 1715 to the southeastern coast, in what is today the Department of Rocha and the southern coast at the mouth of the Río Santa Lucía near Montevideo (Vaz Ferreira, 1955). Devincenzi (1935) enumerates studies mentioning rodents that occur in Uruguay spanning the 130 years beginning with Felix de Azara in 1802 and terminating with Nils Gyldenstolpe in 1932. Of special importance among those mentioned by Devincenzi are the relatively detailed ecological accounts of Waterhouse (1839) who cites the field notes of Charles Darwin taken in 1832, Aplin (1894), and Sanborn (1929). More recently Praderi and Luzardo (1958), Ximénez (1965), Langguth (1963) and Massoia and Fornes (1964) have contributed significant observations. Cabrera and Yepes (1960) provide the only compilation of ecological and natural history information for the more common kinds of South American rodents. Professor Raul Vaz Ferreira, Sr. Alfredo Langguth and Sr. Alfredo Ximénez, as well as other resident biologists, have made a number of important trips to various parts of Uruguay since about 1957. Prior to our own expedition the most important field work was that of Sanborn who, under the auspices of the Captain Marshall Field Brazilian Expedition, spent four months in Uruguay between October 1926 and February 1927. Covering the southern half of the country, he obtained 345 mammals comprising 30 species (Sanborn, 1929) including 12 species of native rodents.

Geography. Uruguay, the smallest country in South America, comprises 131,200 square kilometres and lies between latitudes $30^{\circ} 04^{\prime}$ and $34^{\circ} 55^{\prime} \mathrm{S}$ and longitudes $52^{\circ} 50^{\prime}$ and $57^{\circ} 29^{\prime} \mathrm{W}$. It is bounded on the north by the State of Río Grande do Sul, Brazil, on the west by the Provinces of Corrientes and Entre Ríos, Argentina, on the southeast by the estuarine Río de la Plata, and on the south and east by the Atlantic Ocean.

A gently rolling coastal plain characterizes the southern and eastern parts of the country. Low grassy hills and hogback ridges are found in the central portion. Deeply dissected terminal parts of the Brazilian Plateau and outlying mesa-like hills predominate in the north. However, the highest point $(501 \mathrm{~m})$ in the country is a ridge named Sierra de Animas located near the southern coast in the Department of Maldonado.

Climate. The climate is basically temperate (James, 1942:374), but is characterized by dramatic daily or even hourly weather fluctuations which 
occur in any season. Temperatures are milder in the south and southeast because coastal and adjacent inland areas are subject to the moderating influence of the typically cooler maritime air masses. Recorded temperature extremes are $-5^{\circ} \mathrm{C}$ and $44^{\circ} \mathrm{C}$ (Bergeiro, 1945). Average annual precipitation ranges between $1,193 \mathrm{~mm}$ in the north and $949 \mathrm{~mm}$ in the southwest. Frigid winds, termed pamperos, emanating from Patagonia may flow over the country from the southwest at any season, and they are usually responsible for the rapid and dramatic weather fluctuations mentioned above. In general the climate in conjunction with edaphic factors produces a protracted growing season extending from late August or early September to late May or early June.

Vegetation. The vegetation of Uruguay is transitional between the subtropical woodland of southern Brazil and the open thorn woodland of eastern mesopotamic Argentina. Historically, tall grass savannah predominated in this region. Although $15 \%$ of the total area now comprising Uruguay was forested, woodland now represents only $2 \%$ of the area. The few large tracts remaining are restricted to riparian situations, the steep rocky slopes of larger hills unfit for grazing, and the deep moist canyons of the north. Great coastal marshes (bañados) have developed inland to the beaches at the mouths of rivers and streams flowing into La Plata and the Atlantic Ocean.

\section{Methods}

The expedition was concerned not only with taking mammals but with the preservation of their ectoparasites. Therefore, immediately upon collection, mammals were placed in plastic bags containing pieces of cotton saturated with chloroform, thus preventing the loss of the ectoparasites before they could be systematically removed and preserved in spirits. Although biological data recorded at the time of preparation varied with the mammalian species, the general procedure was to note breeding condition, to save male or female reproductive tracts, to save selectively stomachs for content analysis and, for many small rodents, to make sketches of the pattern of melanin deposition on the inner surface of the skin.

General ecological, ethological and natural history data were recorded in the field. More extensive studies, including excavation of burrows, were undertaken when time permitted. Selective collections of the dominant plants were made at nine stations in order to characterize various habitats.

In the laboratory, moult was studied by examining study skins under a binocular dissecting microscope and observations were compared and correlated with internal melanin patterns previously delineated. In larger forms, the density, length and general condition of the fur were compared in summer and autumn collected specimens to determine the status of the moult.

When possible, breeding condition in males based on the stage of spermatogenesis was verified by microscopic examination of testicular biopsies 1 $\mathrm{mm}$ in diameter, stained with methylene blue, prepared by the squash 
technique. Stomach contents were filtered through a fine silk screen and the residue was separated into plant and animal components.

When sample sizes permitted, age categories based on toothwear, suture closure, and overall body size were determined for various species of rodents. Comparisons of pelage were also used as an aid in aging.

Collecting Stations. An annotated list of our principal collecting stations, arranged in chronological order and followed by an alphabetical listing of localities visited briefly is herein presented. Each numbered collecting station is shown on the map (Fig. 1).

1. Department of Canelones; Arroyo Tropa Vieja. 6-7, 17 December 1962, 5 March 1963. Located $36 \mathrm{~km}$ east of Montevideo, the Arroyo Tropa Vieja, a small marshy stream, dissects a zone of stabilized dunes planted with exotic pines before flowing into the Río de la Plata. The general region, being under development or developed as a resort area, is dotted with cabañas.

2. Department of Lavalleja, Río Cebollatí, $9 \mathrm{~km} S$ Pirarajá. 13-15 December 1962. This was our first camp and was located on an estancia of several thousand hectares owned by a colourful gaucho named Cipitria. The Río Cebollatí here was bordered by a narrow band of riparian thorn woodland. The adjacent upland was heavily grazed.

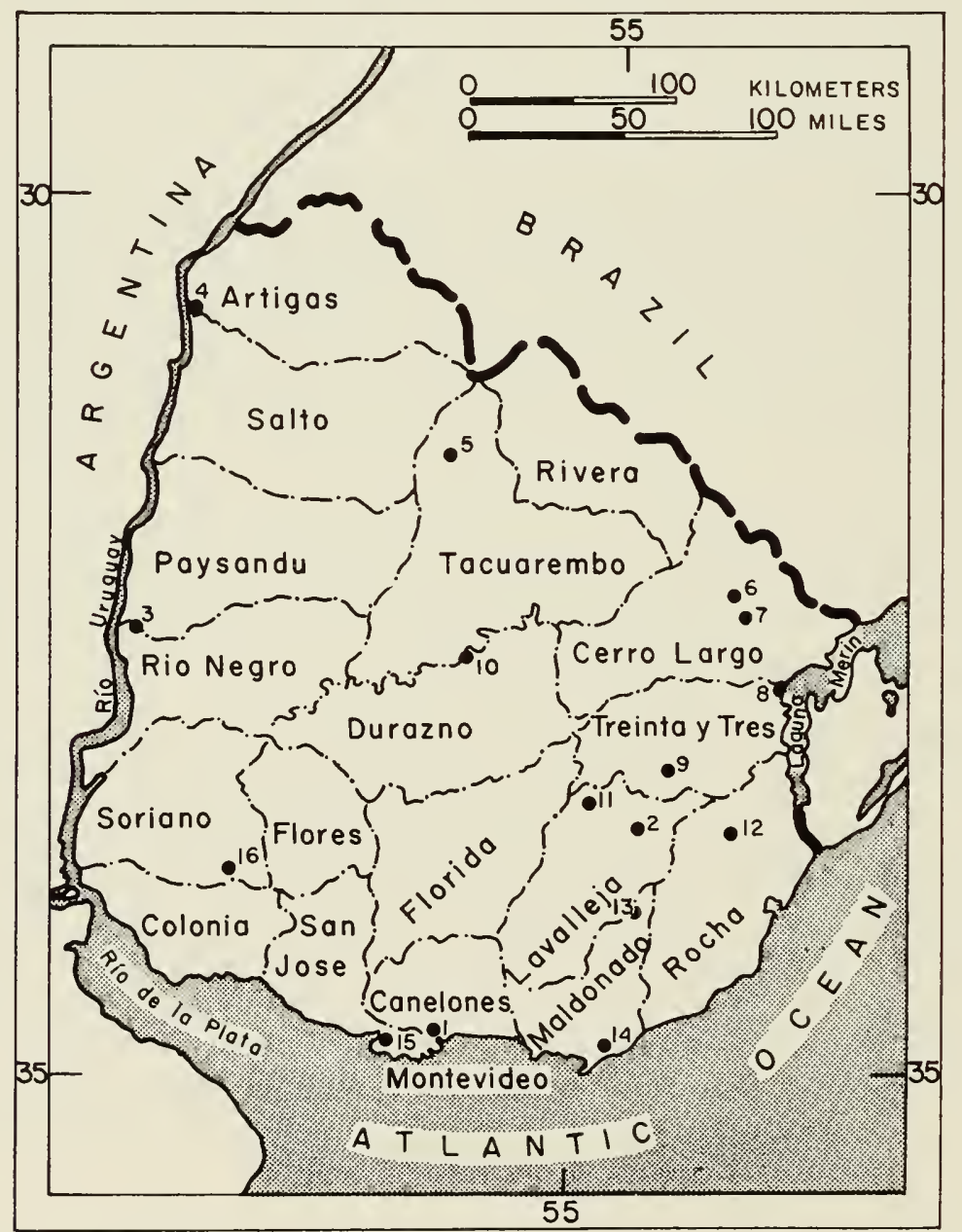

Fig. 1 Uruguay, showing major collecting stations visited by the expedition. The numbers, in chronological order, refer to the accompanying text. 
3. Department of Río Negro; Arroyo Negro, $15 \mathrm{~km} S$ Paysandú. 26 December 1962-7 January 1963. The first place visited by all members of the expedition was on the Estancia Santa Elisa, a ranch of about 10,000 hectares in western Uruguay. Several thousand head of cattle and some sheep were grazed there. Gently rolling overgrazed pasture and low open thorn forest up to $4 \mathrm{~km}$ in width, intergrading with a narrow band of dense riparian woodland along the Arroyo Negro, were the principal habitats.

4. Department of Artigas, $6 \mathrm{~km} \mathrm{NW}$ Belén. 7-21 January 1963. The Estancia Santa Elisa de Yacuy, owned by Sr. Isodor Vejo, included 4,000 hectares of hilly rangeland dotted with granite outcrops. A narrow strip of mature riparian forest grew along the Uruguay River, bordered in places by stands of bunch grass occasionally up to $2 \mathrm{~m}$ in height.

5. Department of Tacuarembó, $40 \mathrm{~km} \mathrm{NW}$ Tacuarembó. 22 January17 February 1963. Toward the end of January we moved to the Estancia El Infiernillo, some 8,000 hectares of forested canyons and grass covered hills. Our camp was situated in the deeply dissected canyon of the Arroyo Tres Cruces in an extensive tract of subtropical forest abundant with ferns and epiphytes. Except during several days of torrential rain that caused extensive flooding, the rocky bed of the stream contained only a series of disjunct pools. In places the slopes of the canyon, rising sharply from the level floor, were crowned by barren vertical granite cliffs. Tree growth typically extended about two-thirds the distance up each slope.

6. Department of Cerro Largo, $6 \mathrm{~km}$ SE Melo. 19 February-6 March 1963. Here we camped $1 \mathrm{~km}$ south of the headquarters of the Estancia Las Marías in a narrow rocky and wooded dell situated in a hilly, sandy-soiled pasture. Several small marshes were present in low-lying drainage areas between the hills. Large limestone boulders, exposed at random, were pitted with small solution caves that served as refuges for a variety of animals.

7. Department of Cerro Largo, $20 \mathrm{~km}$ Melo. 6-21 March 1963. The Río Tacuarí flows from northern Cerro Largo south and then east into the Laguna Merin. We camped within the thorn woodland along the river at the base of grass-covered rocky hills referred to as the Sierra de Vaz. The Estancia Laboramus encompassed this area. The river contained stretches of relatively quiet water, interconnected by narrower rocky, brush-filled rapids.

8. Department of Treinta y Tres, $16 \mathrm{~km}$ SSW Boca del Río Tacuarí. 26 March-6 April 1963. We camped on an estancia along the coast of the Laguna Merin, the large lake separating northeastern Uruguay from southernmost Brazil. Beginning several hundred metres south of camp, dense woodland of willow (Salix humboldtiana) and sarandí (Cephalanthus sp.) extended for several kilometres along the shore. Extensive marsh, at this time mostly dry, and flat grassland predominated inland.

9. Department of Treinta y Tres, Río Olimar Chico, $25 \mathrm{~km} \mathrm{WSW}$ Treinta y Tres. 7-19 April 1963. At this locality the Río Olimar Chico was bordered by a narrow strip of riparian thorn woodland and surrounded by hilly, closely grazed pasture.

10. Department of Durazno, Río Negro, $15 \mathrm{~km}$ NNW San Jorgé. 6-13 April 1963. In the company of members of the Centro de Estudias de Ciencias Naturales, an organization of local amateur and professional naturalists 
from Montevideo, a very profitable side trip was made by two members of the party, Jon C. Barlow and Thomas J. McIntyre. We camped on a wooded hilltop on the shore of the reservoir of the Río Negro and most trapping was done in nearby open thorn woodland.

11. Department of Lavelleja, $12 \mathrm{~km}$ WSW Zapicán. 20-29 April 1963. At this locality Sr. Juan Fernandez graciously hosted most of the party at his estancia, Bella Vista. The ranch, located on a divide known as the Cuchilla de Retamosa, comprised several thousand hectares of hilly prairie. Cattle and sheep were grazed with somewhat varying intensity on different pastures, and eucalyptus groves were scattered here and there.

12. Department of Rocha, $22 \mathrm{~km}$ SE Lascano. 29 April-3 May 1963. El Sauce, an estancia of 18,000 hectares, was the site of our last prolonged encampment. Thousands of cattle and a few sheep were grazed on the rolling grassland dotted with eucalyptus plantings. Except for a very few palms, no native trees grew in the general vicinity of camp. Trapping was done along a stream, principally where a stone fence shielded lush marsh vegetation from livestock.

13. Department of Maldonado, $17 \mathrm{~km}$ NE Aiguá. 13-17 May 1963. This region was characterized by rocky hills covered with low thorn forest rising about $150 \mathrm{~m}$ above the surrounding farmland. One hill, Salamanca, contained a large cave and was the focal point of our collecting activity.

14. Department of Maldonado, Barra del Arroyo Maldonado, $9 \mathrm{~km}$ ENE Punta del Este. 15-17 May 1963. This place was approximately the locality at which Charles Darwin worked in 1832. Three of us lived in a small cabin with a fenced-in yard immediately behind which grew a narrow strip of marsh vegetation dominated by pampas grass (Cortaderia selloana) and caraguatá (Eryngium paniculatum). The marsh was adjacent to the Arroyo Maldonado which flowed southwestward into nearby La Plata. Stabilized dunes extended inland for several kilometres.

15. Department of Montevideo, Río Santa Lucía, $1 \mathrm{~km}$ SE Santiago Vásquez. 25-26 April 1963, 24-26 May 1963. At this locality we trapped in an extensive sali marsh at the edge of the national zoological park, Lecoq.

16. Department of Soriano, $3 \mathrm{~km}$ E Cardona. 22-25 May 1963. Merlin D. Tuttle collected at this place, in southwestern Uruguay, on the estancia of Sr. Julio Gerber. A marshy stream with reeds, cattails, pampas grass and water hyacinths in abundance was the centre of his activity.

No camps were established at the localities listed below:

Department of Artigas, $60 \mathrm{~km} W$ Artigas. 25 January 1963.

Department of Canelones, Bañado de Tropa Vieja. 8 December 1962, 15 January 1963.

Department of Cerro Largo, $10 \mathrm{~km} \mathrm{NW}$ Paso del Dragón. 26 March 1963.

Department of Rocha, $10 \mathrm{~km}$ E Velázques. 30 April 1963.

Department of Tacuarembó, $10 \mathrm{~km} N$ Tacuarembó. 22 January 1963.

Department of Tacuarembó, $15 \mathrm{~km} \mathrm{NW}$ Tacuarembó. 15 February 1963.

Department of Trienta y Tres, $10 \mathrm{~km} W$ Boca del Río Tacuarí. 26 March 1963. 


\section{Species Accounts}

The sequence of families and genera used in this report is from Simpson (1945). Specific and subspecific names are from Hershkovitz (1966) for Scapteromys, from Hershkovitz (1962) for Calomys, from Hershkovitz (1959 b) for Reithrodon, from Hershkovitz (1959 a) for Wiedomys, from Talice and Momigliano (1954) for Ctenomys, and from Cabrera (1957, 1961) for all other names. For the sake of convenience within genera, species are arranged in alphabetical order. Common names of mammals in Spanish are from Devincenzi (1935) and Cabrera and Yepes (1960). Scientific names of plants are after Herter (1930).

Check-list. The following list includes the 21 species comprising 17 genera, and 8 families of the order Rotentia known to have occurred in Uruguay within the last 150 years. The present status of each species is indicated as species introduced into the country $(\mathrm{x})$; species obtained by our expedition (*), and species believed to be extirpated $(\dagger)$. Species not marked are thought still to occur in Uruguay but were not obtained by the expedition and their status is poorly known.

ORDER RODENTIA-rodents

Family Cricetidae-native rats and mice

* Oryzomys delticola Thomas

* Oryzomys flavescens (Waterhouse)

* Thomasomys oenax Thomas

* Akodon azarae azarae (Fischer)

* Akodon obscurus obscurus (Waterhouse)

* Oxymycterus rufus nasutus (Waterhouse)

* Scapteromys tumidus (Waterhouse)

* Calomys laucha laucha (Desmarest) Wiedomys pyrrhorhinos Hershkovitz

* Reithrodon physodes physodes Olfers

* Holochilus brasiliensis vulpinus (Brants)

* Holochilus magnus Hershkovitz

Family Muridae-old world rats and mice

* Rattus rattus ssp. (Linnaeus)

$\mathrm{x}$ Rattus norvegicus (Berkenhout)

$\mathrm{x}^{*}$ Mus musculus ssp. Linnaeus

Family Erethizontidae-porcupines

Coendu spinosus ssp. (F. Cuvier)

Family Caviidae-guinea pigs

* Cavia pamparum Thomas

Family Hydrochoeridae-capybaras

* Hydrochoerus hydrochaeris uruguayensis (C. Ameghino and Rovereto)

Family Chinchillidae-vizcachas $\mathrm{x} \dagger$ Lagostomus maximus (Desmarest)

Family Capromyidae-nutrias

* Myocastor coypus bonariensis (Commerson)

Family Ctenomyidae-tuco-tucos

* Ctenomys torquatus Lichtenstein 
Plan of the Accounts. The accounts of the species include data on distribution and abundance, ecology, behaviour, food habits, breeding and moult. The emphasis in these accounts is upon new information. Most specimens mentioned in the text are housed in the American Museum of Natural History (AMNH). However, a few are in the collection of the Sociedad de Taguato (ST) of Montevideo. The metric system is used for all measurements. In sections on breeding $\mathrm{CR}$ equals crown-rump length of embryos. Data are taken from unpublished field notes of R. G. Van Gelder, S. Anderson, K. Koopman, A. Langguth, A. Ximénez, A. Tocchéton, M. D. Tuttle, T. J. McIntyre and J. K. Bouseman as well as from my own notes. The absence of a bibliographic reference, when the observations of these men are cited in a species account, indicates that the information was obtained from the unpublished data.

\section{Oryzomys delticola Thomas}

Arboreal rice rat

Specimens: Total 62; Artigas, 6 km NNW Belén, o ; Cerro Largo, 6 km SE Melo, ơ, San Jorgé, $15 \sigma^{\nearrow} \sigma^{\nearrow}, 17$ o\%; Lavalleja, $12 \mathrm{~km}$ WSW Zapicán, ơ, Maldonado, 17 km NE Aiguá, ơ; Tacuarembó, 40 km NW Tacuarembó, $4 \sigma^{7} \sigma^{7}, 5$ \%ᄋ, 3 ? sex; Treinta y Tres, Río Olimar Chico, 25 km WSW Treinta y Tres, $5 \sigma^{\top} \sigma^{\top}, 5$ ㅇ․

Ecology. Oryzomys delticola is the common woodland mouse of Uruguay. It is found in mesic subtropical forest with a closed canopy and a scanty understory as in Tacuarembó and in more xeric, open thorn woods with dense to moderate understory as in Durazno along the Río Negro. Conspicuous vegetation at the latter locality includes espinillo (Acacia caven), Xilosoma warburgi, coronilla (Scutia buxifolia), arrayán (Blepharocalyx tweediei), Baccharis sp., quiebra-arados (Heima salicifolia) and zarzaparrilla (Smilax campestris). We trapped this mouse along fallen logs, around outcrops, among tangles of vines near streams, and in trees up to $2 \mathrm{~m}$ above the ground. It has also been taken in tall grass bordering woodland (Praderi and Luzardo, 1958:30) and in houses (Langguth, 1963:13). In Tacuarembó at Infiernillo it was taken in the same line with Thomasomys oenax and in Durazno with Akodon azarae.

Shelter. Oryzomys delticola does not make runways on the ground but rather follows natural avenues and runways of other animals. Praderi and Luzardo (1958:31) found a nest of this species in a wooden box lodged 2 $\mathrm{m}$ up in the crotch of a thorn tree. In Durazno I saw one of these mice leaving a burrow beneath a large rock on a wooded slope.

Behaviour. Since most of our specimens were taken at night $O$. delticola is judged to be primarily nocturnal. However three, one a young male (AM NH 205956), were trapped at mid-day and a female (AMNH 205928) was shot in mid-afternoon as she foraged in a garbage pit at our campsite near Melo. 
In Durazno I observed several individuals by lantern light shortly after dark as they climbed about in trees and over large rocks in search of food. They are agile and are regarded by Langguth (1963) to be better adapted for climbing than the congeneric $O$. flavescens because they have longer tails than that species.

Parasites and Predators. Two mice (AMNH 305970; AMNH 205924) each had a large cuterebrid larva beneath the epidermis of their left flanks. Other ectoparasites preserved have been identified, and results will be published elsewhere.

Post-cranial elements of a skeleton thought to be Oryzomys delticola were found in the stomach of an Ihering owl (Aegolius iheringi harrisi) netted in Tacuarembó (Barlow and Cuello, 1964:517). Langguth (1963: 13) reported remains of this mouse in pellets of the barn owl (Tyto alba tnidara). A partially digested $O$. delticola (AMNH 205927) was regurgitated by a green snake (Philodryas aestivus) captured near Melo.

Food Habits. Oryzomys delticola, although primarily herbivorous, includes more animal material in its diet than does $O$. flavescens and has been readily trapped when pieces of fish were used for bait. Four stomachs contained about $10 \%$ insect remains, including a larva (Pyralidae [Lepidoptera]), one nymph (Aphidae [Homoptera]) and fragments of Coleoptera and Hemiptera not identifiable to family. The stomach is single-chambered and not noticeably muscularized or glandularized.

Breeding. Information concerning reproductive status was available for 52 of the 62 specimens obtained. None of the six adults taken in January, March and May were in breeding condition, but this sample is too small to be truly indicative of reproductive activity during those months. Two of four adult females obtained in March were pregnant and two of four adult males taken in this month had testes of breeding size, i.e. $7 \mathrm{~mm}$ or greater in length, as determined by histological examination.

Populations sampled in early April at two widely separated localities in the country demonstrated asynchrony in their respective breeding schedules. Two of three adult females obtained along the Río Olimar Chico in Treinta y Tres were pregnant, in contrast to none of 13 females trapped along the reservoir of the Río Negro in Durazno, although one individual from the latter locality had a post-partum uterus containing four placental scars, two in each horn. However, the capture of several juveniles in Durazno suggested that reproductive activities had only recently ceased. Two of five adult males from Treinta y Tres had scrotal testes of breeding size, in comparison to three of nine adult males in Durazno with scrotal testes of breeding size. The five pregnant females taken during our work contained an average of 3.4 (2-4) embryos. Fourteen embryos were in the right uterine horn and three were in the left. In this species the lack of the relatively large samples which are available for May for most of the other commonly collected cricetines results in an incomplete picture of reproduction for summer and autumn. Thus on the basis of the data presented here it is only possible to say that Oryzomys delticola breeds in late summer and early autumn. 


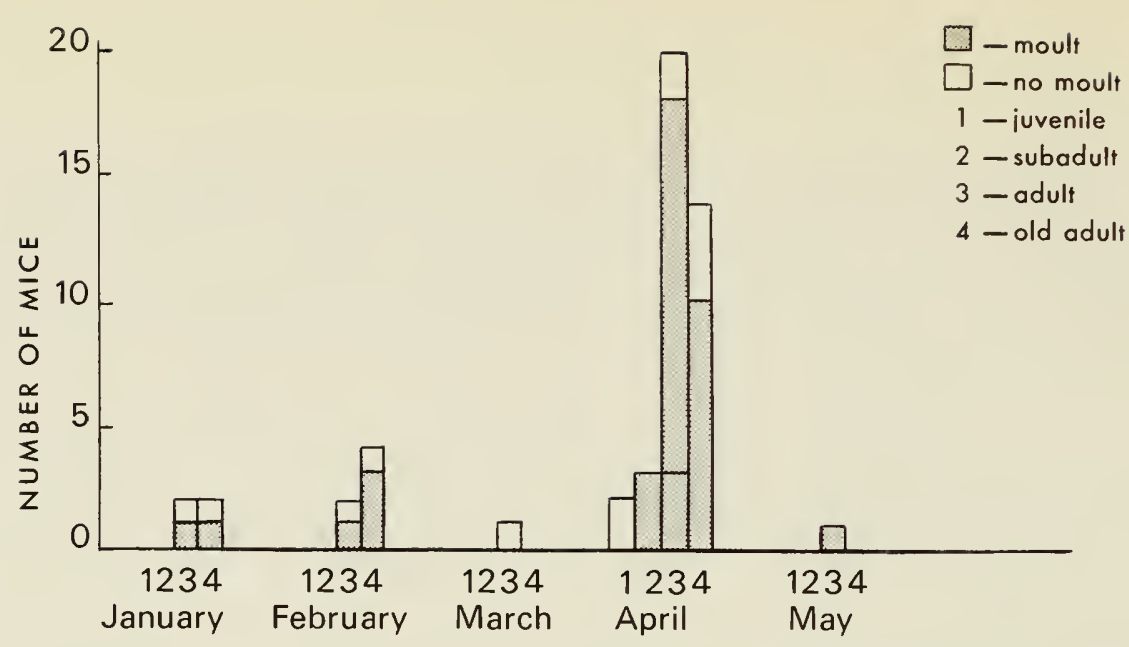

Fig. 2 Moult in Oryzomys delticola by age classes between January and May 1963. Analysis based on 50 skins.

Moult. Four age categories based on the wear of the molar occlusal surfaces, and on total (head and body + tail) length were recognized in this species:

Class 1, juvenile-Molars unworn; total length less than $160 \mathrm{~mm}$; pelage short, grayish on dorsum, light gray on venter.

Class 2, subadult-Molars moderately worn but with crown pattern not obscured; total length between 161 and $180 \mathrm{~mm}$; pelage of varying length contingent upon season and wear, light grayish brown on dorsum, grayish white on venter.

Class 3, adult-Molars heavily worn, cusp pattern partly obliterated, especially that of the third molars; total length between 181 and $228 \mathrm{~mm}$; pelage grayish brown or reddish brown on dorsum, whitish on venter.

Class 4, old adult-Molars very heavily worn; on all, cusp pattern partly or nearly completely obliterated; total length between 229 and $258 \mathrm{~mm}$; pelage, as in Class 3.

Classes 2 to 4 obtained in summer (January to mid-March) generally had worn, short pelage conspicuously paler than that of autumn-caught individuals. Individuals in moult were obtained in both seasons (Fig. 2). Data from the two widely separated populations sampled in early April demonstrate that moult and reproductive activity may occur concurrently in both sexes. Specimens from Treinta y Tres included pregnant females in the moult, and moulting males with enlarged, scrotal testes were trapped in Durazno.

No juveniles were moulting. A male (AMNH 205949) having subadult characteristics was in the post-juvenile moult (Fig. 3). The soft, grayish juvenile pelage was being replaced by coarser reddish-brown hair. New growth began ventrally, then continued up the sides to the back, and proceeded from a mid-dorsal centre anteriorly and posteriorly.

The autumnal moult in adult individuals resembles that of other Uruguayan cricetines examined. A growth centre first develops on the mid-belly, and hair replacement proceeds anteriorly and posteriorly from it. Then the moult spreads up the sides to the mid-dorsum, resulting in the formation of the characteristic "saddle" configuration. From this secondary centre, moult spreads anteriorly and posteriorly. New growth seems to lag somewhat on the head and two variations are seen. Moult occurs first on the sides of the head and the new growth spreads upward to meet on the mid-line of the muzzle, 


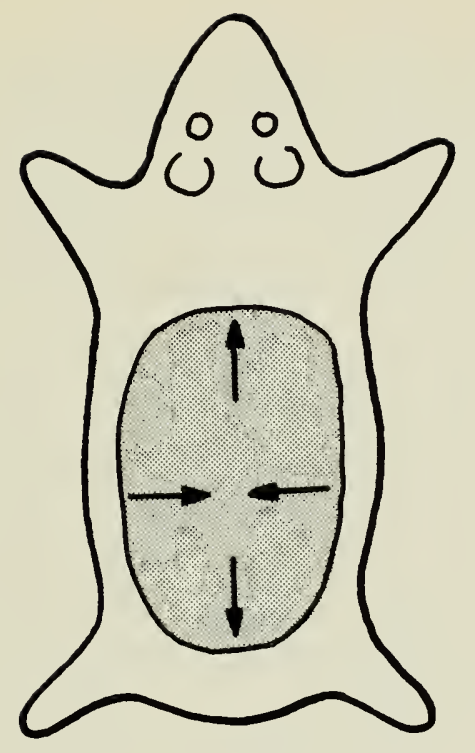

Fig. 3 Post-juvenile moult in a subadult $\hat{\sigma}$ of Oryzomys delticola ( $A M N H$ 205949) as seen in the exterior view of the dorsum (arrows show direction of hair growth).

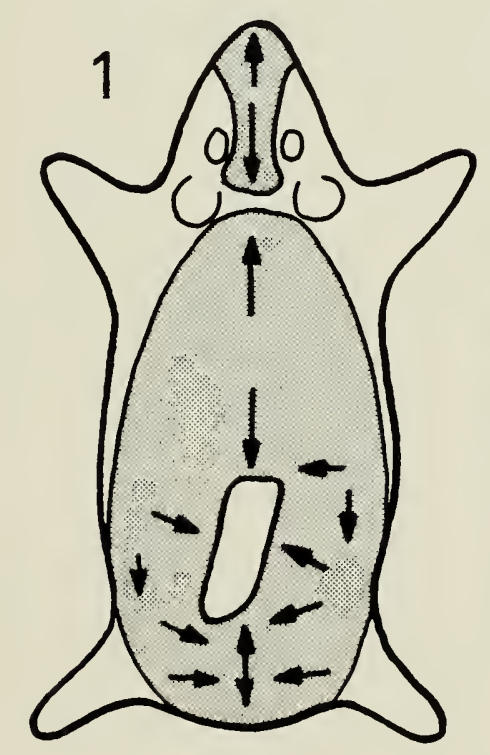

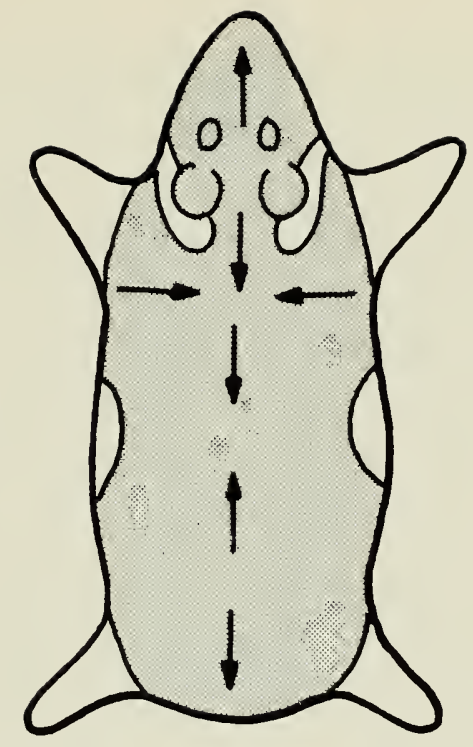

Fig. 4 Autumnal moult in an adult i Oryzomys delticola ( $A M N H$ 205938), as demonstrated in a dorsal exterior view, showing two growth centres (arrows show direction of hair growth).

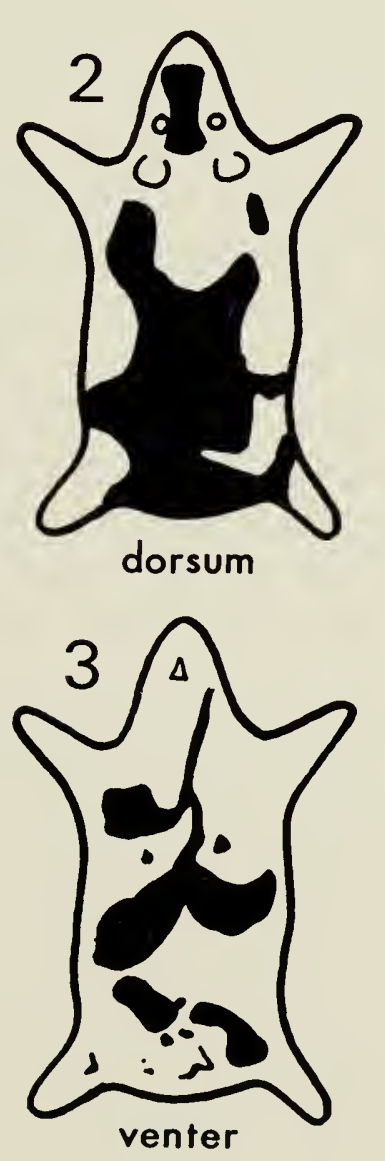

Fig. 5 Autumnal moult in an older adult + Oryzomys delticola ( $A M N H$ $205961)$ showing dorsal exterior view (1; arrows show direction of hair growth) with the corresponding dorsal interior pattern of melanin deposition (2). Also shown is the ventral interior pattern of melanin deposition (3). 
whence moult grows posteriorly over the crown and converges between the ears with the main growth wave of the dorsum. Or moult may begin independently on the muzzle from a separate centre and later join tracts from the sides of the head passing along the neck from the principal moult of the thorax. From the centre on the muzzle, hair replacement then proceeds caudally in the way already described.

Moult patterns of old adults are more complicated than those of younger mice. One female (AMNH 205938) had a centre between the ears from which hair replacement proceeded anteriorly to the tip of the snout and also posteriorly to a zone in the middle of the back, where the moult converged with another moulting front passing anteriorly from another growth centre located anterior to the rump (Fig. 4). A breakdown in the simpler pattern of development followed in subadult mice is characteristic of older adults. Additional growth centres develop, and hair replacement more often progresses to the tip of the muzzle from a growth centre between the ears, rather than from the tip of the muzzle posteriorly to convergence between the ears. A large pregnant female (AMNH 205961), taken on 26 April in Lavalleja, near Zapicán, had three growth centres on the dorsum from which moult was progressing both anteriorly and posteriorly (Fig. 5). The melanin on the interior of this skin was deposited in a highly irregular pattern.

\section{Oryzomys flavescens (Waterhouse)}

Pampas rice rat, colilargo chico

Specimens: Total 32; Artigas, $6 \mathrm{~km}$ NNW Belén, ð7, ? sex; Cerro Largo, $20 \mathrm{~km}$ SE Melo, $\sigma^{\nearrow}$; Lavalleja, $12 \mathrm{~km}$ WSW Zapicán, $2 \sigma^{\Upsilon} \sigma^{\nearrow}, 2$ ㅇ; Maldonado, Barra del Arroyo Maldonado, $9 \mathrm{~km}$ ENE Punta del Este, १, ? sex; Montevideo, Río Santa Lucía, $1 \mathrm{~km}$ SE Santiago Vásquez, ð’, \%; Rocha, $22 \mathrm{~km}$ SE Lascano, $8 \sigma^{\nearrow} \sigma^{x}, 11$ \% ; Soriano, $3 \mathrm{~km}$ E Cardona, ○; Treinta y Tres, 16 km SSW Boca del Río Tacuarí, ơ?.

Ecology. We found that Oryzomys flavescens generally frequents stands of tall grass in marshes and along rivers and streams in Uruguay, but at one locality in Lavalleja we obtained specimens around corn shocks at some distance from water. In Maldonado, along the Arroyo Maldonado, in a trapline overlapping several distinct vegetational zones within a marshy area, $O$. flavescens was taken most frequently in pure stands of pampas grass (Cortaderia selloana) and junco (Juncus acutus), although a pregnant female (AMNH 206013) was caught in a trap actually floating in shallow water at the base of some rushes. Scapteromys tumidus and Akodon obscurus were taken in the same trapline, but most often in parts of the habitat that were on the average wetter and with a somewhat different vegetational aspect (mixed Eryngium sp. and C. selloana). In general, Oxymcterus rufus was the most frequent associate of $O$. flavescens in wet tall grass situations. $O$. flavescens apparently does not make runways of its own but rather follows 
natural pathways through the grass or utilizes runways of other small rodents, especially Cavia pamparum.

Food Habits. The single-chambered stomach of $O$. flavescens possesses neither hypertrophied muscularization of the cardiac region nor conspicuous glandularization of the fundic region. Each of 10 stomachs examined contained green plant material. Five of these also contained some invertebrate remains. Parts of a beetle (Chrysomelidae) were found in the stomach of one individual (AMNH 206013) trapped 3 May 1963, near Lascano, Department of Rocha.

Breeding. Of the total of 14 adult females taken in January, March, April and May, 12 showed evidence of breeding. The only female obtained in January was lactating. April and May apparently are months of peak reproductive activity as eight of ten females in some phase of the breeding cycle were pregnant. These females averaged 5.1 (3-7) embryos apiece with 25 implantations in the right uterine horn and 16 in the left.

In males examination of histological preparations of testicular biopsies demonstrated that testes measuring at least $7 \times 5 \mathrm{~mm}$ contained quantities of mature sperm. Seven adults with scrotal testes of that size or larger were trapped between March and May. Two adult males obtained by Langguth (pers. comm.) on 18 September 1963, at Tropa Vieja, Department of Canelones, had testes measuring $5 \times 3 \mathrm{~mm}$ and $6.5 \times 4 \mathrm{~mm}$ respectively, that would have been by the above criterion less than reproductively active size.

Moult. Individuals demonstrating various stages of moult are known from March, April, May and September. Both breeding and non-breeding adults collected in April and May were moulting, and there was no relationship between status of the moult and breeding condition (the two were independent: $\mathrm{X}^{2}=.202[\mathrm{~ns}], \mathrm{df}=1$ ).

Three adults collected in January (AMNH 205787) and March (AMNH 205988,206017 ) were in the short summer pelage. Age groups were established with criteria similar to those used for $O$. delticola as the pattern of moult development closely resembles that species. Three of five individuals collected in April and nine of 20 taken in May were moulting.

Too few specimens are available to diagnose in detail the pattern of growth demonstrated in the post-juvenile moult. However, a young male (AMNH 206012) measuring $187 \mathrm{~mm}$ in total length was in heavy moult dorsally and ventrally. Growth on the mid-venter in this animal was progressing in a caudal direction. Latero-ventrally the line of growth passed up over the flanks and converged on the latero-dorsum. From this newly formed centre hairs grew both posteriorly and anteriorly to the tip of the muzzle. The incoming hair was a brighter yellowish-brown than the old pelage.

Moult in adults develops as in most other species examined, with ventral growth centres appearing first from which moult spreads up over the flanks and toward the mid-dorsum; initial convergence of these lateral growth fronts forms a "saddle" pattern. Growth proceeds both anteriorly and posteriorly from this initial site on the dorsum. The epidermis is a golden colour when the black tips of the guard hairs first break through the surface of the skin. The golden colour gives way to a salmon pink when the hairs are about 
half grown and to black just prior to the completion of growth. Salmon and black colouration on the exterior are represented on the interior of the skin by bluish-black areas of melanin. Examination of specimens suggests that moult lags on the head and rump. Moreover, all vestiges of hair replacement elsewhere disappear significantly in advance of completion of hair growth on the head and rump. No irregular moult patterns such as found in the very old individuals of Scapteromys tumidus were seen.

\section{Thomasomys oenax Thomas}

Red-nosed tree mouse, ratón del sur de Brazil

Specimens: Total 4; Tacuarembó, $40 \mathrm{~km} \mathrm{NW}$ Tacuarembó, $3 \sigma^{7} \sigma^{x}$, .

This rare arboreal mouse was known only from four specimens taken in the State of Río Grande do Sul, Brazil, until Vaz Ferreira (1960:67) reported its occurrence in Uruguay. Another specimen is now known from Curitibá, State of Paraná, Brazil (Avila-Pires, 1960:2). Pellets of the barn owl, Tyto alba, found in southern Tacuarembó, contained several skulls of this mouse (Sr. A. Langguth, pers. comm.). We obtained four additional specimens of Thomasomys oenax in one month of trapping in dense subtropical wocdland in the canyon of the Arroyo Tres Cruces, $40 \mathrm{~km} \mathrm{~N}$ of Tacuarembó, Department of Tacuarembó.

General Description. Thomasomys oenax resembles the larger oryzomines in body form, except that the tail is much longer. In colour the dorsum is pale gray with a yellowish cast. The venter is buffy white. The tip of the muzzle and the lightly haired ears are bright ochraceous and there is another ochraceous patch on the rump. The long tail is haired and uniformly buffy. The largest adult (AMNH 206021) obtained by us measured: total length, $315 \mathrm{~mm}$; length of tail, $186 \mathrm{~mm}$; length of hind foot with claw, $30.5 \mathrm{~mm}$; ear from notch, $22 \mathrm{~mm}$; weight, $61.3 \mathrm{gm}$. Three individuals were considered to be young adults and the other (AMNH 206020) a subadult on the basis of tooth wear.

Range. Thomasomys oenax occurs from Curitibá, Paraná, Brazil, south into Uruguay to southern Tacuarembó and thus is a resident of the zone of transition between extensive subtropical forest and more temperate savannah. In Uruguay the species appears to be restricted to patches of dense subtropical woodland characteristic of the Brazilian Plateau region in north central parts of the country. It has not been found in adjacent parts of Artigas, Salto and Cerro Largo, which differ significantly from Tacuarembó in topography and character of vegetation.

Ecology. The four mice were caught in 4400 trap nights in mesic subtropical woodland. Conspicuous vegetation included canelón (Rapanea ferruginea), arrayán (Blepharocalyx tweediei), Cupania verna'is, Octea acutifolia, Maytenus ilicifolia, blanquillo (Sebastiana klotzschiana) and espina amarilla (Berberis laurina). These trees, festooned with bromeliads (Tillandsia aoranthos), as well as ferns (Polypodium phyllitides and Aneimia tomentosa) and lichen (Usnea hieronimii), constitute dominants of a type of sub- 
tropical woodland characteristic of Río Grande do Sul in southern Brazil. Such forest is less common in Uruguay. The general aspect was of low $(7 \mathrm{~m})$ to medium-sized $(14 \mathrm{~m})$ forest with a nearly continuous canopy. Understory was sparse and consisted primarily of ferns and saplings of the dominant trees. The forest growth spread two thirds of the way up the rocky canyon walls before appreciably thinning.

The first specimen (AMNH 206018), obtained 27 January, was trapped among large rocks within the forest on the north facing slope of the canyon and was the only mouse caught in a line of 50 Museum Special traps. The second specimen (AMNH 206019), taken 8 February, was trapped $20 \mathrm{~m}$ from the first in a trap placed at a height of $2 \mathrm{~m}$ in a tree on a lateral branch $10 \mathrm{~cm}$ in diameter. Here all trees were $7 \mathrm{~m}$ or less in height. The third individual (AMNH 206020), obtained 10 February, was trapped in the crotch of a tree $11 / 2 \mathrm{~m}$ above the ground and within $4 \mathrm{~m}$ of the site of capture of the first specimen. The fourth mouse (AMNH 206021), taken 11 February, was trapped in the same tree and on the same branch as the second individual. The third and fourth were adult males in breeding condition. Suitable habitat that stretched along $1 \frac{1}{2} \mathrm{~km}$ in the canyon was sampled intensively for nearly a month but additional specimens were not secured.

The only other cricetine obtained within the same habitat, both on the ground and in trees, was Oryzomys delticola. Two Akodon azarae were trapped at the forest edge in bunch grass, and a Calomys laucha was obtained in the upland rocky pasture, above the canyon.

Food Habits. Stomachs of three of the mice contained about $6 \mathrm{cc}$ of greenish plant material, bait and purplish berries from the arbol malo (Lithraea molleoides [Anacardiaceae]). This species is widely distributed in Uruguay. In the study area fruiting trees were abundant on the lower and middle parts of the north facing slope of the canyon.

Breeding. The young female (AMNH 206020) was not pregnant. The testes of the smallest male (AMNH 206018) were ant-eaten and could not be measured. The two largest males had testes measuring $10 \times 6 \mathrm{~mm}$ that contained abundant mature sperm in the epididymides and the seminiferous tubules.

Moult. No indication of moult was found on the specimens. The type specimen, in the British Museum (Nat. Hist.), was also secured in summer and was not in the moult (Karl Koopman, pers. comm.).

Remarks. Ximénez (1965:135) has reported two specimens of Wiedomys pyrrhorhinos from the Arroyo Tres Cruces in Tacuarembó. Since this is the same locality at which our examples of Thomasomys oenax were collected I questioned the original identification of our specimens. Sydney Anderson (pers. comm.) reports that our specimens are definitely $T$. oenax and differ from the description of $W$. pyrrhorhinos of Hershkovitz (1959a) in (1) larger size, (2) underparts not well defined from colour of sides, (3) basal part of ventral hairs dark grey, (4) supra-orbital region parallel-sided and square, not ridged, and (5) mesolophostyle functional, rather than low and obsolescent or absent. In addition the Uruguayan specimens differ from 
the holotype of $W$. pyrrhorhinos (housed in the American Museum) in characters 1 through 3. I briefly examined the type of Thomasomys oenax in the British Museum (Nat. Hist.) and did not find it to differ conspicuously in any characters included in my notes on our Uruguayan specimens of this species.

\section{Akodon azarae azarae (Fischer)}

Field mouse, ratón de las arenas

Specimens: Total 70; Artigas, $60 \mathrm{~km} \mathrm{~W}$ Artigas, $20^{7} 0^{7}$, o ; $6 \mathrm{~km} \mathrm{NNW}$

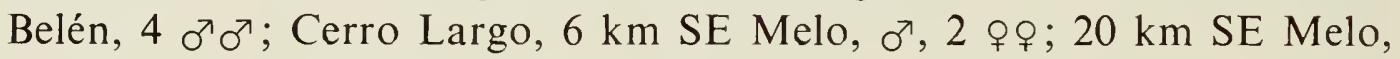
$0^{x}$; Durazno, Río Negro, $15 \mathrm{~km}$ NNW San Jorgé, $20^{x} o^{x}, 4$ \% ; Lavalleja, Río Cebollatí, $9 \mathrm{~km} \mathrm{~S}$ Pirarajá, $q ; 12 \mathrm{~km}$ WSW Zapicán, $90^{x} o^{x}$, 9 qo; Maldonado, $17 \mathrm{~km}$ NE Aiguá, $20^{7} 0^{x}$, o; Río Negro, Arroyo Negro, $15 \mathrm{~km} \mathrm{~S}$ Paysandú, $\sigma^{7}$; Rocha, $22 \mathrm{~km} \mathrm{SE}$ Lascano, 13 o $\sigma^{7} \sigma^{7}, 11$ १९; Soriano, $3 \mathrm{~km}$ E Cardona, $2 \sigma^{\top} \sigma^{\top}, 2$ ๆ\%; Tacuarembó, $40 \mathrm{~km} \mathrm{NW}$ Tacuarembó, o, ? sex.

Ecology. Akodon azarae occurs in a variety of habitats in Uruguay. We took it in open thorn woodland dominated by Acacia sp. and with a dense understory of Baccharis sp. and Eupatorium sp.; in tall grass (Scirpus giganteus) adjacent to riparian woodland; at the edge of a brush pile in dense riparian woodland; and in upland stands of tall grass (Andropogon sp.). A. azarae also has been taken in dry places in marshes. In Rocha, a stone wall passing through a stream-fed marsh afforded a higher and drier refuge for this mouse, and individuals apparently were living within crevices in the wall. Reithrodon physodes also was obtained along this wall. In edge situations Oryzomys delticola was commonly trapped with this Akodon. Akodon azarae was also trapped with Akodon obscurus, Oxymycterus rufus and Oryzomys flavescens in marshy areas with a variety of conspicuous plants. An adult male (AMNH 206061) was trapped at the edge of a drainage strip of short green grass between harvested grain fields, several kilometres from open woodland in Río Negro. Although no burrows or runways definitely attributable to Akodon azarae were found, it is certain that these mice were utilizing crevices within a stone wall in Rocha. Faeces were found on rocks immediately in front of holes in the wall. In Durazno I found a subadult individual in a shallow excavation beneath a board.

Fornes and Massoia (1965:106) found $A$. azarae equally active at night and in the day at Miramar, Buenos Aires Province, Argentina. In Uruguay we found $A$. azarae to be mainly nocturnal. $A$. obscurus seems to be primarily diurnal, and where these species are ecologically sympatric, competition may be reduced by differences in time of activity.

Parasites. Nine of 65 individuals trapped between December and May demonstrated active myiasis or scars from infestation by cuterebrid larvae. Only Oryzomys delticola demonstrated a similar incidence of parasitism.

Food Habits. The stomach is simple and unspecialized. Eleven stomachs contained $20 \%$ plant material, $10 \%$ Anthony's bait, and $70 \%$ remains of invertebrates. 
Invertebrate material, on the basis of the per cent of stomachs containing the item that had been eaten, was identified as follows: Coleoptera (Scarabaeidae, Carabidae, Chrysomelidae) 90.9\%; Orthoptera (Gryllidae, Gryllotalpidae) 45.4\%; Hymenoptera (Formicidae, Ichneumonidae) 45.4\%; Lepidoptera (Noctuidae) 27.2\% ; Isoptera (Termitidae) $9.9 \%$; Hemiptera (Tingidae) $9.9 \%$; Diptera (Sciaridae) 9.9\%; Oligochaeta $9.9 \%$.

Breeding. Females $150-159 \mathrm{~mm}$ in length had post-partum uteri and were lactating. Some males of similar size had scrotal testes $7 \mathrm{~mm}$ in length containing few mature sperm. Few data are available for the period from June through August; however, the breeding season is obviously protracted, perhaps year round. Pearson (1967:55) reports a breeding season extending from October to April in A. azarae collected near Buenos Aires, Argentina. All available data for 1963 from Uruguay show a reproductive period extending from October through May (Table 1). Actually the breeding season is at least a month longer, as demonstrated by a female (ST 40), taken 27 September 1957 in Canelones, that contained five embryos (CR $=17 \mathrm{~mm}$ ). Males with scrotal testes measuring in excess of $8 \mathrm{~mm}$ in length were taken in January, February, March, April, May, October and December. Twelve females taken in February, April, May, September and October, either pregnant or with placental scars, averaged four (3-7) embryos per pregnancy. Thirty-five embryos were in the right uterine horn and 25 were in the left one. Five other females taken in April and May were lactating.

Moult. As there was no difference in pattern, colour or texture, it was not possible to distinguish the post-juvenile from adult moults. However, by comparison with other Uruguayan cricetines, moults in subadults and young adults that emanated from only one or two growth centres were considered close to the post-juvenile developmental pattern. A typical sequence of moult development is depicted in Fig. 6. In subadults the autumn moult begins from a pair of latero-ventral centres, extending, from a position just cephalad to the posterior limbs, forward in a band only a few millimetres wide to a position just cephalad to the anterior limbs. Growth proceeds onto the belly first and then upward from the lateral centre toward the dorsal mid-line. Growth on the dorsum and venter seems to proceed at about the same rate in the early and middle stages of development, but the ventral moult is completed first. On the venter the wave of moult spreads simultaneously anteriorly, posteriorly and toward the ventral mid-line. The "saddle-back" condition is developed just anterior to the rump on the dorsum, more rarely in the scapular region. No examples were found with the "saddle" developed in the middle of the back. Two waves of moult, one on each side of the mid-dorsum, may pass forward laterally in advance of the wave progressing anteriorly along the mid-dorsum; or the mid-dorsal growth waves may progress more rapidly than the lateral area. Moult on the head, although varying in pattern, is simply a continuation of the dorsal body moult spreading forward to the tip of the muzzle. Older adults, $190 \mathrm{~mm}$ or longer, demonstrate several additional growth centres, including one that develops on the posterior part of the mid-dorsum prior to the arrival in this area of the waves of moult advancing toward the mid-line from the sides. An additional growth centre on the tip of the muzzle spreads posteriorly. 

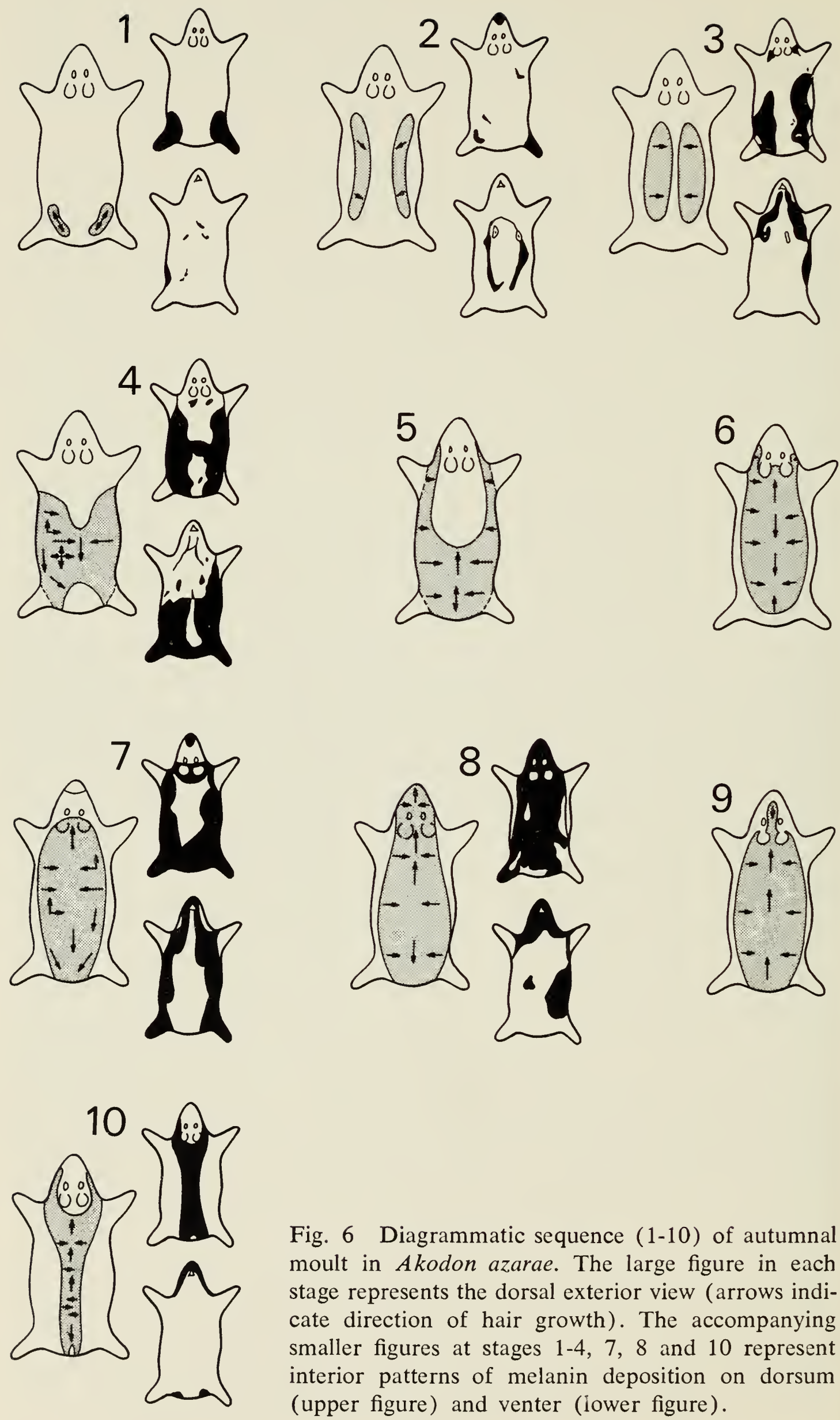

Fig. 6 Diagrammatic sequence (1-10) of autumnal moult in Akodon azarae. The large figure in each stage represents the dorsal exterior view (arrows indicate direction of hair growth). The accompanying smaller figures at stages $1-4,7,8$ and 10 represent interior patterns of melanin deposition on dorsum (upper figure) and venter (iower figure). 
Table 1

Reproductive status of Akodon azarae*

$\frac{\overline{\sigma^{\nearrow} \sigma^{\nearrow}} \text { Total Specimens } \text { 우 }}{\text { Adult }}$

Month Locality Juv. $\overline{\text { Non-br. Breed. Juv. Non-br. Breed. Totals }}$

**December Lavallaja (Río

Cebollatí)

Río Negro

\begin{tabular}{lll}
1 & & \\
\hline 1 & 1 & 2 \\
\hline
\end{tabular}

\begin{tabular}{lllll}
\hline January & Artigas & & 4 & \\
\\
& Tacuarembó & & 1 & \\
\cline { 2 - 5 } & & 4 & 1 & 5 \\
\hline February & Cerro Largo (6 km & 1 & 2 & \\
\cline { 2 - 5 } & SE Melo) & 1 & 2 & 3 \\
\hline March & Cerro Largo (20 km & 1 & & \\
\cline { 2 - 5 } & SE Melo) & 1 & & 1 \\
\hline
\end{tabular}

\begin{tabular}{lllllllll}
\hline April & Durazno & & 1 & & 1 & 1 & 1 & \\
& Lavalleja & 1 & 1 & 7 & 4 & 1 & 4 & \\
\cline { 3 - 8 } & & 1 & 2 & 7 & 5 & 2 & 5 & 22 \\
& & &
\end{tabular}

\begin{tabular}{|c|c|c|c|c|c|c|c|}
\hline \multirow[t]{3}{*}{ May } & Maldonado $(17 \mathrm{~km}$ & 1 & & 1 & & \multirow{2}{*}{\multicolumn{2}{|c|}{$\begin{array}{l}6 \\
2\end{array}$}} \\
\hline & \multirow[t]{2}{*}{ Soriano } & 4 & $\begin{array}{l}9 \\
2\end{array}$ & 2 & 3 & & \\
\hline & & 4 & 12 & 2 & 4 & 8 & 30 \\
\hline \multirow[t]{2}{*}{ August } & \multirow[t]{2}{*}{ San José } & 1 & & & 2 & & \\
\hline & & 1 & & & 2 & & 3 \\
\hline \multirow{2}{*}{\multicolumn{2}{|c|}{ September Canelones }} & & & & \multicolumn{3}{|l|}{1} \\
\hline & & & & & 1 & & 1 \\
\hline
\end{tabular}

\begin{tabular}{lllll}
\hline October Colonia & 2 & 1 & \\
\cline { 2 - 5 } & & 2 & 1 & 3 \\
\hline
\end{tabular}

\begin{tabular}{llc}
\hline November Canelones & 1 & \\
\cline { 2 - 3 } & 1 & 1 \\
\hline
\end{tabular}

*Includes specimens taken by A. Langguth between August and November 1963.

**1962 
The youngest individuals, $150 \mathrm{~mm}$ and less in length, were not in the moult. Since lactating females, only $159 \mathrm{~mm}$ long and considered to be adults, were in the moult, it is suggested that the post-juvenile moult occurs in individuals between $150-158 \mathrm{~mm}$ in total length.

Specimens were available for all months except June, July and September. At least some individuals collected between August and December showed a light moult generally confined to the dorsal surface of the head. Specimens collected between January and May had more conspicuous moult over the body. This was especially true in April and May, when the autumnal moult was underway.

\section{Akodon obscurus obscurus (Waterhouse)}

Marsh akodon, ratón obscuro

Specimens: Total 74; Artigas, 6 km NNW Belén, क; Canelones, Arroyo Tropa Vieja, $4 \sigma^{7} \sigma^{7}, 3$ 우; Cerro Largo, $6 \mathrm{~km}$ SE Melo, 3 우; $20 \mathrm{~km}$ SE Melo, бð; Maldonado, 17 km NE Aiguá, ơ; Barra del Arroyo Maldonado, 9 km ENE Punta del Este, $5 \sigma^{\gamma} \sigma^{\gamma}, 5$ $\%$; Montevideo, Río Santa Lucía, $1 \mathrm{~km}$ SE Santiago Vásquez, 3 ఠ $\sigma^{\top}, 4$ 우; Rocha, $22 \mathrm{~km}$ SE Lascano, 20 ఠౌ $\sigma^{\top}, 13$ ㅇ; Tacuarembó, 40 km NW Tacuarembó, ? sex; Treinta y Tres, $16 \mathrm{~km}$ SSW Boca del Río Tacuarí, $6 \sigma^{\nearrow} \sigma^{\top}, 3$ 웅? sex.

Ecology. Akodon obscurus is restricted to limnic habitats. It was taken in inundated places having plentiful vegetation where traps could only have been reached by swimming mice. Only Scapteromys tumidus was also found in these wet places. In drier parts of marshes, A. obscurus was associated with Oryzomys flavescens, $A$. azarae and Oxymycterus rufus. This akodon is apparently diurnal as most individuals were trapped in the day.

Food Habits. Stomach contents show Akodon obscurus to be primarily entomophagous. One of seven stomachs examined contained only plant material. The remaining six on the basis of the per cent of stomachs containing the item included arthropod material as follows: Coleoptera (Scarabaeidae, Tenebrionidae) 83.3\% ; Orthoptera (Gryllidae) 66.6\% ; Homoptera (Cicadellidae) 16.6\%; Lepidoptera 16.6\%; Diptera 16.6\%; Arachnida 16.6\%.

Breeding. Males obtained in December, April and May had subscrotal testes measuring $6 \times 3 \mathrm{~mm}$ or less and were not in breeding condition. Apparently, the breeding season is protracted, as pregnant females are known from October and February and lactating females have been trapped in December, April and May. A female (ST 35), obtained 22 October 1957 in the Department of San José, contained four embryos $(C R=17 \mathrm{~mm})$; a female (AMNH 206100), trapped 23 February 1962 in Cerro Largo, had three embryos $(C R=6 \mathrm{~mm})$; and a lactating female (AMNH 206145), caught 8 May 1963 in Rocha, showed five placental scars. So many of our specimens lack data that it has not been possible to demonstrate the ratio of breeding to total monthly sample in this species. It is noteworthy that $27.3 \%$ ( 9 of 33 ) individuals taken in May were juveniles. 

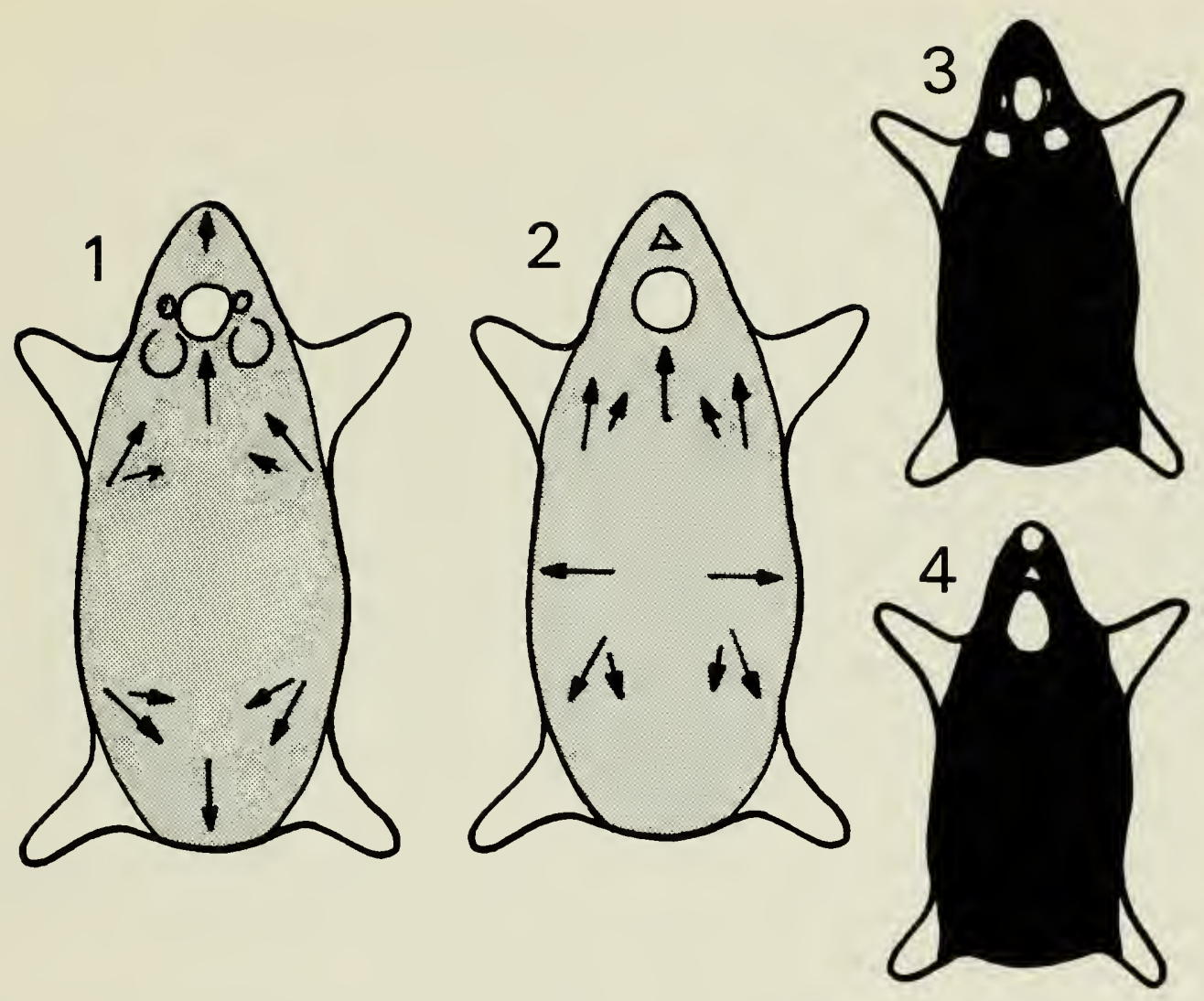

Fig. 7 Post-juvenile moult in a subadult to young adult of Akodon obscurus ( $A M N H$ 206125). Shown are dorsal exterior (1) and ventral (2) views (arrows show direction of hair growth) and corresponding patterns of dorsal interior (3) and ventral (4) melanin deposition.

Moult. Progression of the moult is similar to Akodon azarae. Age categories were determined as with other cricetines. A number of subadults taken in early May were in heavy post-juvenile moult (Fig. 7). A young adult male (AMNH 206125) taken 4 May 1963 in Rocha, showed melanin deposition over the entire interior of the skin except for a single patch. Evidence of moult was found on some animals obtained in the months of February, April, May, June, September, October and December.

Remarks. Massoia (1963:240) has recently reported Akodon kempi Thomas from Uruguay. Sydney Anderson (pers. comm.) notes that neither Thomas (1917) nor Massoia (1963) compare kempi with obscurus and that the characters that distinguish kempi from $A$. azarae are those that separate obscurus, including specimens from the type locality (Maldonado, Department of Maldonado) collected by us, from our specimens of $A$. azarae. Anderson considers kempi conspecific with obscurus. I examined the types of $A$. obscurus and $A$. kempi in the British Museum (Nat. Hist.) and found the type of the latter to be a subadult specimen of obscurus. 


\section{Oxymycterus rufus nasutus (Waterhouse)}

Burrowing mouse, ratón rojo

Specimens: Total 42; Canelones, Arroyo Tropa Vieja, $4 \sigma^{\nearrow} \sigma^{7}, 4$ 우 우 Cerro

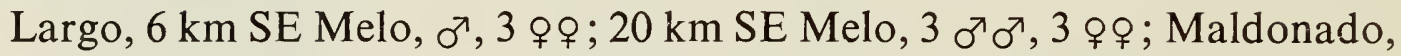
Barra del Arroyo Maldonado, 9 km ENE Punta del Este, $3 \sigma^{\nearrow} \sigma^{\nearrow}, 4$ $\%$; Rocha, $22 \mathrm{~km}$ SE Lascano, $8 \sigma^{\nearrow} \sigma^{\nearrow}, 8$ 우; Soriano, $3 \mathrm{~km}$ E Cardona, $\sigma^{\nearrow}$.

Ecology. Oxymycterus rufus occurs in wet meadows with stands of bunch grass (Paspalum sp.); tall grass adjacent to streams and rivers; and drier parts of marshy areas among clumps of pampas grass (Cortaderia selloana) outside the frequently inundated zone. Although taken in the same trapline with the hydrophilic Scapteromys tumidus and Akodon obscurus, O. rufus was most often taken in the slightly drier places frequented by Oryzomys flavescens, with which it was commonly associated. Massoia and Fornes (1964:294) have noted that Oxymycterus sp. swims only from necessity and that in water the pelage of this species quickly becomes thoroughly soaked.

O. rufus constructs no runways of its own but uses those of Cavia pamparum, the broad trails of Hydrochoerus hydrochaeris in stands of tall bunch grass, or natural pathways through such vegetation.

Odour. An example caught in a live trap smelled strongly of an odour distinctly reminiscent of acrolein (acrylic aldehyde), a chemical used commercially to warn of leakage of toxic odourless gases from mechanical systems (Brewster, 1953:173). This acrid, penetrating scent may serve a similar warning function in these rodents, possibly serving to discourage potential predators.

Endoparasites. Seven of 12 stomachs from individuals captured in March, April and May were infested with between six and more than 30 nematodes of the genus Protospirura ( $P$. muricola, $P$. muris; J. Ubelaker, pers. comm.). The stomach of an eighth individual, a female (AMNH 206192), contained a single Capillaria hepatica.

Food Habits. These red mice are primarily entomophagous, although many other kinds of invertebrates are eaten. Glandular and structural modifications of the stomach include a thickening of the fundus. This and other characters presumably associated with the entomophagous habit are shared with North American grasshopper mice (Onychomys; Horner, Taylor and Padykula, 1964: 523). The contents of 12 stomachs analyzed in detail comprised invertebrate material, on the basis of the per cent of stomachs containing the item, as follows: Coleoptera (Tenebrionidae, Scarabaeidae, Lampyridae, Chrysomelidae, Carabidae, Pselaphidae, Dytiscidae) $100.0 \%$; Hymenoptera (Formicidae) 83.3\%; Diptera (Sciaridae, Bibionidae, Chironomidae, Tipalidae) 83.3\% ; Hemiptera (Tingidae, Pentatomidae) 41.6\%; Orthoptera (Gryllidae, Acrididae, Gryllacrididae) 25.0\%; Lepidoptera (Noctuidae, unidentified families) $25.5 \%$; Homoptera (Cicadellidae, Fulgoridae) $16.6 \%$; Oligochaeta (earthworms) 33.3\%; Chilopoda (centipedes) $25.0 \%$; Gastropoda (slugs) 16.6\%; Aranea 16.6\%; plants (unidentified fragments) $16.6 \%$. 
In many marshy places Scapteromys tumidus and Oxymcterus rufus are the principal insectivorous rodents. The two differ in micro-habitat preferences and time of activity; Oxymcterus rufus is primarily diurnal, although specimens have been trapped at dusk and in the early evening. Consequently competition with the nocturnal Scapteromys tumidus would probably be minimal.

Breeding. Available data indicate that the breeding season of this mouse is protracted (Table 2) in Uruguay. Females were taken only in February, March, May, September and December but samples for each of these months included pregnant or lactating individuals. Likewise, males with scrotal testes of breeding size ( $9 \times 6 \mathrm{~mm}$ and larger, as demonstrated by histologic analysis of testicular biopsies) were found in the above months. Seven gravid females averaged 2.1 (1-4) embryos ranging in length from 4 to $29 \mathrm{~mm}$ in length. Twelve embryos were in the left uterine horn and three were in the right. Massoia and Fornes (1964:294) reported a female with six embryos. Oxymycterus rufus possesses eight nipples, and litters larger than those indicated by the embryo counts might be expected.

Table 2

Reproductive status of Oxymycterus rufus*

$\frac{\sigma^{\top} \sigma^{\Upsilon} \text { Total Specimens } \text { \% }}{\text { Adult }}$

Month Locality Juv. Non-br. Breed. Juv. Non-br. Breed. Totals

\begin{tabular}{|c|c|c|c|c|c|c|c|c|}
\hline \multirow[t]{2}{*}{ December } & \multirow[t]{2}{*}{ Canelones } & 1 & 1 & \multicolumn{2}{|l|}{2} & 2 & \multicolumn{2}{|l|}{1} \\
\hline & & 1 & 1 & 2 & & 2 & 1 & 7 \\
\hline \multirow[t]{3}{*}{ February } & Canelones & & & & & & 1 & \\
\hline & Cerro Largo & & & 1 & & 2 & 1 & \\
\hline & & & & 1 & & 2 & 1 & 5 \\
\hline \multirow[t]{2}{*}{ March } & Cerro Largo & & 1 & 2 & & 2 & 1 & \\
\hline & & & 1 & 2 & & 2 & 1 & 6 \\
\hline \multirow[t]{4}{*}{ May } & Maldonado & & 2 & 1 & 1 & 3 & & \\
\hline & Rocha & 1 & 4 & 3 & 1 & 1 & 6 & \\
\hline & Soriano & & & 1 & & & & \\
\hline & & 1 & 6 & 5 & 2 & 4 & 6 & 24 \\
\hline \multirow[t]{2}{*}{ September } & Canelones & & & 2 & & 4 & 3 & \\
\hline & & & & 2 & & 4 & 3 & 9 \\
\hline
\end{tabular}

*Includes data of A. Langguth (pers. comm.). 

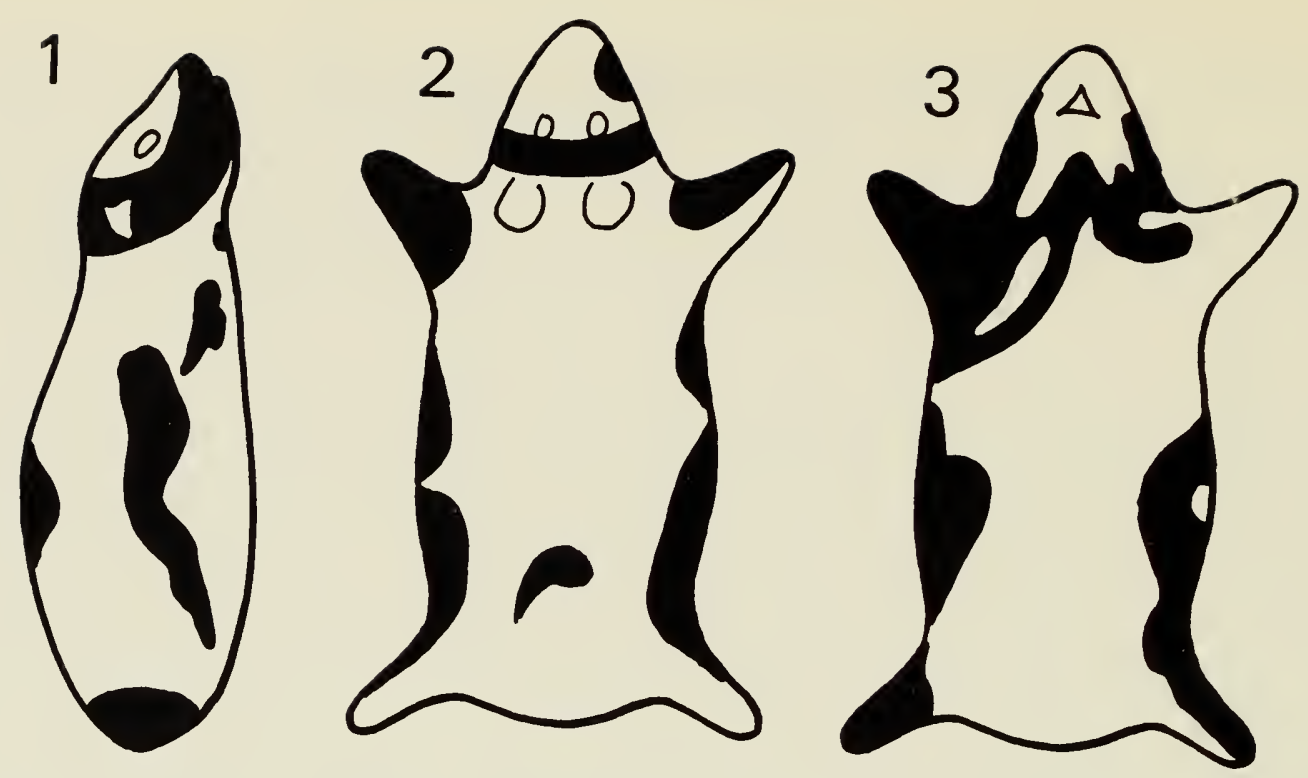

Fig. 8 A typical autumnal moult pattern found among specimens of Oxymycterus rufus ( $9, A M N H$ 206191). The diagrams represent (1) lateral, (2) dorsal and (3) ventral views of the melanin deposition on the interior surface of the skin.

Moult. Because age categories within groups of individuals in adult pelage were difficult to establish in this species, moult patterns were not traced in detail. In some specimens narrow lateral bands of new growth from which hair replacement was progressing toward the mid-dorsum and toward the mid-venter were noted. But most of these also had additional growth centres on the dorsum and venter (Fig. 8). On the mid-dorsum an obvious "saddle-back" condition develops and growth proceeds both anteriorly and posteriorly from this secondary growth centre (Fig. 9). Hair replacement is completed on the head and rump last. On the head hair grows posteriorly from the tip of the muzzle and converges with growth progressing anteriorly from the mid-dorsum. Moult apparently may occur at any season, as individuals showing some hair replacement have been taken in January, February, March, May, September, October, November, and December. Moult into adult winter pelage seemingly begins in late March and continues through May.
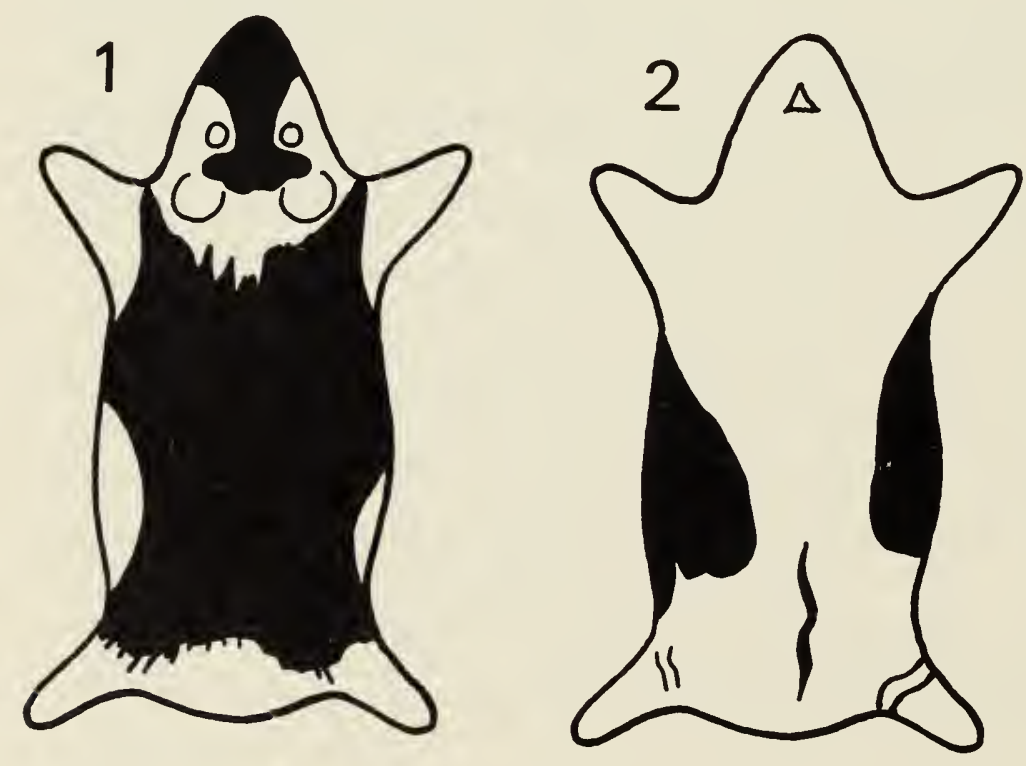

Fig. 9

"Saddle-back" stage of moult development in Oxymycterus rufus ( ô, AMNH 206182) as demonstrated by dorsal (1) and ventral (2) views of the melanin deposition on the interior surface of the skin. 


\section{Scapteromys tumidus (Waterhouse)}

Swamp rat, rata de bañado

Specimens: Total 123; Canelones, Arroyo Tropa Vieja, $15 \sigma^{\top} \sigma^{\top}, 18$ \% ; Cerro Largo, 6 km SE Melo, $2 \sigma^{\top} \sigma^{\nearrow}$; Maldonado, Barra del Arroyo Maldonado, $9 \mathrm{~km}$ ENE Punta del Este, $7 \sigma^{\gamma} \sigma^{\gamma}, 9$ \% ; Montevideo, Río Santa Lucía, $1 \mathrm{~km}$ SE Santiago Vásquez, $2 \sigma^{\top} \sigma^{\top}, 5$ ㅇ; Rocha, $22 \mathrm{~km}$ SE Lascano, $2 \sigma^{\top} \sigma^{\top}$; Soriano, $3 \mathrm{~km}$ E Cardona, $21 \sigma^{\top} \sigma^{\nearrow}, 24$ ㅇ; Treinta y Tres, 16 km SSW Boca del Río Tacuarí, $8 \sigma^{\nwarrow} \sigma^{\nwarrow}, 10$ ㅇ.

Prior to 1950 Scapteromys tumidus was represented from Uruguay by only a few specimens. These included the type from Maldonado (Waterhouse, 1839:15), a specimen obtained by Aplin (1894:308) and at least one taken in Soriano in 1924 by W. E. Budin (Hershkovitz, 1966:98). Sanborn (1929:158) trapped extensively in marshy places and along waterways, but did not obtain this species.

Ecology. Often Scapteromys tumidus was found in marshy or low places where the dominant plants were Eryngium sp. and Cortaderia selloana and the ground between the plants was soggy. In many coastal areas regular inundation occurred. In Argentina in the delta of the Paraná and at Punta Lara (Buenos Aires Province) Massoia and Fornes (1964:291) found Scapteromys tumidus in frequently flooded places dominated by stands of Cortaderia sp. and the false cortaderia (Scirpus giganteus). Along the Laguna Merin in Treinta y Tres, Eryngium sp. grew in isolated patches from $2 \mathrm{~m}$ to more than $15 \mathrm{~m}$ in diameter and Scapteromys tumidus, Akodon obscurus and Cavia pamparum were common there. At this place Scapteromys tumi$d u s$ was also taken in a swampy area within woodland dominated by Salix humboldtiana. Cavia pamparum, Akodon obscurus, Oxymycterus rufus and Oryzomys flavescens were the commonest associates of Scapteromys tumidus in moderately wet places. In the wettest areas, as in parts of the salt marsh along the Río Santa Lucía in the Department of Montevideo, only Akodon obscurus occurred with Scapteromys. In Soriano, in a wet meadow with bunch grass $1 \mathrm{~m}$ tall and an understory of Bermuda grass (Cynodon dactylon), Scapteromys tumidus was taken with Oxymycterus rufus and Akodon azarae. Scapteromys tumidus was less abundant, or absent, in those wet meadows and small marshes in which a variety of grasses and composites (such as Baccharis sp.) predominated, as at Sierra de Vaz, Cerro Largo, and in Rocha, near Lascano.

Swamp rats seem not to make runways of their own, but rather follow any open route through the vegetation or frequently use the abundant runways of Cavia pamparum. Near the Laguna Merin, swamp rats moved between clumps of taller vegetation in closely grazed pasture without runways. Swamp rats dig to obtain food, but there is no evidence that they excavate burrows. We searched at various collecting sites in Uruguay where Scapteromys tumidus was common and found no burrows attributable to these swamp rats. Massoia and Fornes (1964:293) found beneath matted vegetation shallow depressions containing nestling young which might have been excavated. 
Vocalization. Vocalizations are often heard when animals are in distress. We heard high pitched squeals when these rats were first caught in traps. Massoia and Fornes (1964:293) reported a variety of vocalizations, including a sharp cry, phonetically chi-chi, emitted by nestling young, a sonorous adult call, ro-ro-ro, not unlike one of the songs of the wren, Troglodytes aedon, and a sharp, clicking cry of excitement, crec-crec-crec.

Time of Activity. Although most individuals were trapped at dusk or in the night, 30\% of all specimens were obtained between 7:00 a.m. and 5:00 p.m. Diurnal activity may be correlated with high population levels or increased nutritional needs. The majority of animals taken in the daytime were juveniles, subadults, or pregnant females in contrast to night catches comprised predominantly of adult males. Massoia (1961:124) found Scapteromys to be nocturnal and crepuscular in Argentina. When traps were checked by us on an hourly basis, from 6:00 p.m. to 1:00 p.m., $90 \%$ of the individuals were found to be trapped between 6:00 p.m. and 10:00 p.m. A few rats were caught at dawn.

Parasites. Only one individual (AMNH 206314), a male with scrotal testes, demonstrated possible cuterebrid infection. A circular area of scar tissue, with a growth of new hair, $1 \mathrm{~mm}$ in length, was located on the right side of the throat. Cysts of unidentified cestodes, often several per individual, were noted in the livers of about $40 \%$ of the swamp rats so examined. A single nematode worm (Pharyngodon sp.) was found in the stomach of one female (AMNH 206261).

Niche. Scapteromys tumidus is of moderate to large size. It is semiaquatic, occupying marshy places and frequently inundated areas, where it eats mostly invertebrates and some plant material. Scapteromys tumidus is as aquatic as the primarily herbivorous species of Holochilus often found in similar habitats. Oxymycterus rufus, which is primarily insectivorous, is likewise found in wet meadows and marshes. However, it lacks the waterproofed pelage of Scapteromys tumidus and swims only when necessary (Massoia and Fornes, 1964:294).

Excellent swimming ability and agility in climbing contribute to the success of Scapteromys tumidus in frequently inundated areas. The predominately insectivorous mouse Akodon obscurus, a smaller ecological counterpart of $S$. tumidus, also occurs in frequently inundated places and swims well. A. obscurus is more distinctly diurnal than S. tumidus, and this difference in activity periodism may reduce competition.

Food Habits. Scapteromys tumidus, like Oxymycterus rufus, has a largely insectivorous diet. Stomach contents of 11 individuals obtained in April and May were $85 \%$ invertebrate. The other $15 \%$ included Anthony's bait used in trapping and plant material-mostly the skins of an unidentified fruit and the seeds of Raphanus sp. (Cruciferae). In Argentina, the species demonstrates a preference for oligochaetes (Massoia and Fornes, 1964:295). Only two of 18 stomachs of Uruguayan specimens contained parts of oligochaetes; a third stomach contained two leeches. In all stomachs analyzed Coleoptera, especially scarabiid beetles, predominated. In captivity a Scapteromys tumidus readily accepted slices of carrot and pieces of cheese. 
The contents of the stomachs of the 11 individuals mentioned above, on the basis of the per cent of stomachs containing the item, included the following: Coleoptera (Scarabaeidae [Melolonthinae], Chrysomelidae, Carabidae, Elateridae) $100.0 \%$; Hymenoptera (Formicidae) 45.5\%; Orthoptera (Gryllidae, Acrididae 27.2\% ; Lepidoptera (Noctuidae, Pyralididae, unidentified caterpillars) 27.2\%; Diptera (Sciaridae, Tipulidae [Limoniinae]) 27.2\% ; Hemiptera (Coreidae) 18.1\% ; Isoptera (Termitidae) 9.1\%; Aranea, Oligochaeta, Hirudinea, Gastropoda (snail) $27.2 \%$; plants, Cruciferae (Raphanus sp.), unidentified berries $27.2 \%$.

Although resembling Oxymycterus rufus in dietary habits, Scapteromys tumidus lacks the distinctively bilobular stomach with a glandularized fundic region possessed by the former species. However, the stomach of $S$. tumidus is characterized by some muscularization in the cardiac region and there is some thickening of the fundic region that may be glandular tissue.

Breeding. Males with scrotal testes at least $12 \mathrm{~mm}$ long had abundant mature sperm both in the seminiferous tubules and in the epididymides. Males with testes of at least minimum breeding size have been found in every month of the year except January, June and July, months for which no males were available (Table 3). In April and May, 97\% of all adult males had testes of breeding size. Pregnant females were taken in December 1962, April and May 1963 by the expedition, and in October and November 1963 by Sr. Alfredo Langguth (pers. comm.).

Most specimens in breeding condition could be satisfactorily placed in one of the adult age categories (see the following section on moult). One individual, a female (AMNH 206251) with teeth worn nearly to the roots, was somewhat smaller than normal adult size.

Of the embryos observed, 25 were implanted in the left uterine horn and 19 in the right. The average number of embryos and/or young was four (3-5). This seems low in view of the fact that females possess four pairs of nipples. In a non-pregrant female (AMNH 206261) with an open vagina, obtained on 26 April, the nipples were pink and slightly swollen and the lacteal tissue had hypertrophied; however, no milk could be expressed.

Moult. For convenience, I recognize four age-classes of Scapteromys tumidus based, as with Oryzomys delticola, on the wear of the molars, especially $\mathrm{M}^{3}$, and on the combined body and tail length. The classes are:

Class 1, juvenile- $\mathrm{M}^{3}$ not erupted and other molars unworn; pelage significantly darker on both dorsum and venter than in older age-classes; total length, less than $225 \mathrm{~mm}$.

Class 2, subadult- $\mathrm{M}^{3}$ erupted, all molars slightly worn; pelage as in adults; total lengths from $226 \mathrm{~mm}$ through $299 \mathrm{~mm}$.

Class 3, adult $-\mathrm{M}^{3}$ moderately worn, other molars with cusp pattern so worn as to be partly obscured; the adult pelage is described elsewhere; total lengths from $300 \mathrm{~mm}$ through $325 \mathrm{~mm}$.

Class 4 , old adult-Molars heavily worn, cusp pattern completely obliterated, the occlusal surface often being smoothly concave; pelage as in adults, but somewhat more grizzled; total length, $326 \mathrm{~mm}$ and greater. 
Table 3

Reproductive status of Scapteromys tumidus

$\frac{\sigma^{7} \sigma^{7} \text { Total Specimens } \text { क } \%}{\text { Adult }}$

Month Locality Juv. Non-br. Breed. Juv. Non-br. Breed. Totals

\begin{tabular}{llllllll}
\hline December & Canelones & 3 & 2 & 5 & 4 & 5 & 8 \\
\cline { 2 - 6 } 1962 & 3 & 2 & 5 & 4 & 5 & 8 & 27 \\
\hline
\end{tabular}

\begin{tabular}{|c|c|c|c|}
\hline \multirow[t]{2}{*}{ February* } & $\begin{array}{l}\text { Cerro Largo } \\
(6 \mathrm{~km} \text { SE Melo }) \\
\text { Canelones }\end{array}$ & 2 & 1 \\
\hline & & 2 & 1 \\
\hline
\end{tabular}

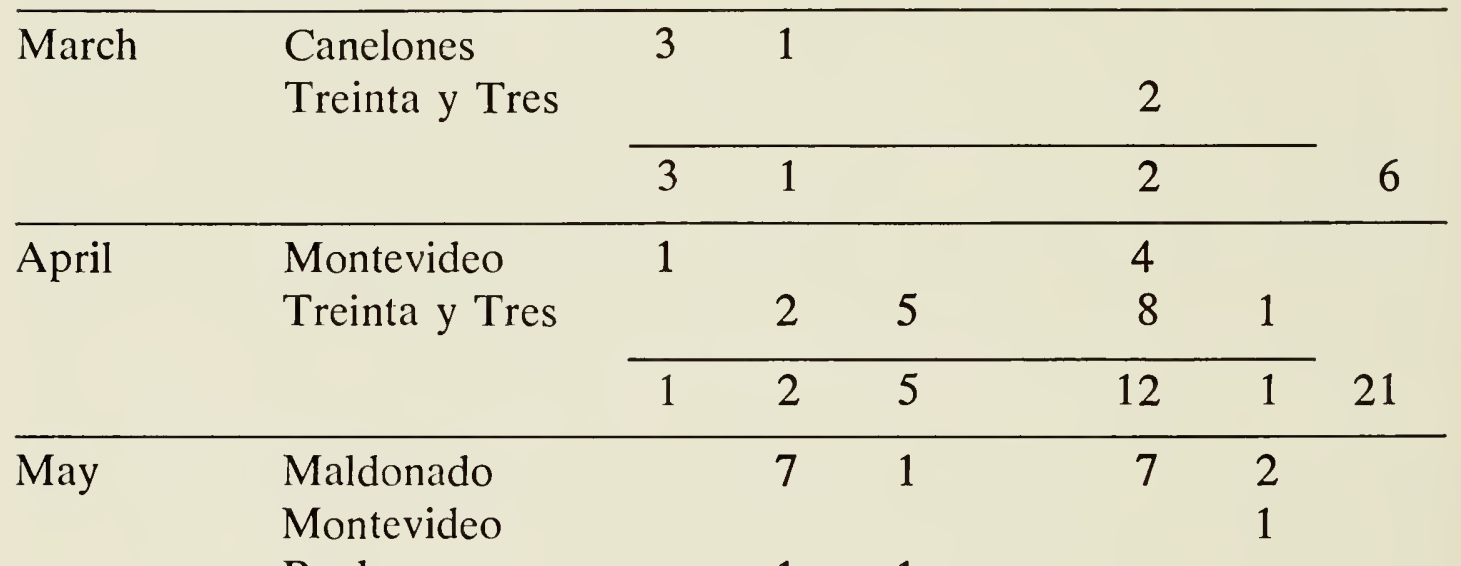

\begin{tabular}{lrrrrrr} 
Rocha & & 1 & 1 & & & \\
Soriano & 1 & 11 & 8 & 9 & 14 & 2 \\
\cline { 2 - 6 } & 1 & 19 & 10 & 9 & 21 & 5
\end{tabular}

\begin{tabular}{llllll}
\hline August & San José & & & 1 & 3 \\
\cline { 3 - 4 } & & & 1 & 3 & 4 \\
\hline September & Canelones & 3 & 2 & 7 & \\
\cline { 3 - 5 } & & 3 & 2 & 7 & 12 \\
\hline
\end{tabular}

\begin{tabular}{llllllll}
\hline October & $\begin{array}{l}\text { Canelones } \\
\text { Colonia }\end{array}$ & & 1 & & & & \\
& & 1 & 2 & 1 & 1 & \\
\cline { 2 - 6 } & & 1 & 3 & 1 & 1 & 6 \\
\hline November & Canelones & & & 2 & & 1 & \\
& Montevideo & & 1 & 1 & & \\
& & & 3 & 1 & 1 & 5 \\
\cline { 3 - 6 } & & & & & & 149
\end{tabular}

*All remaining data for 1963. 


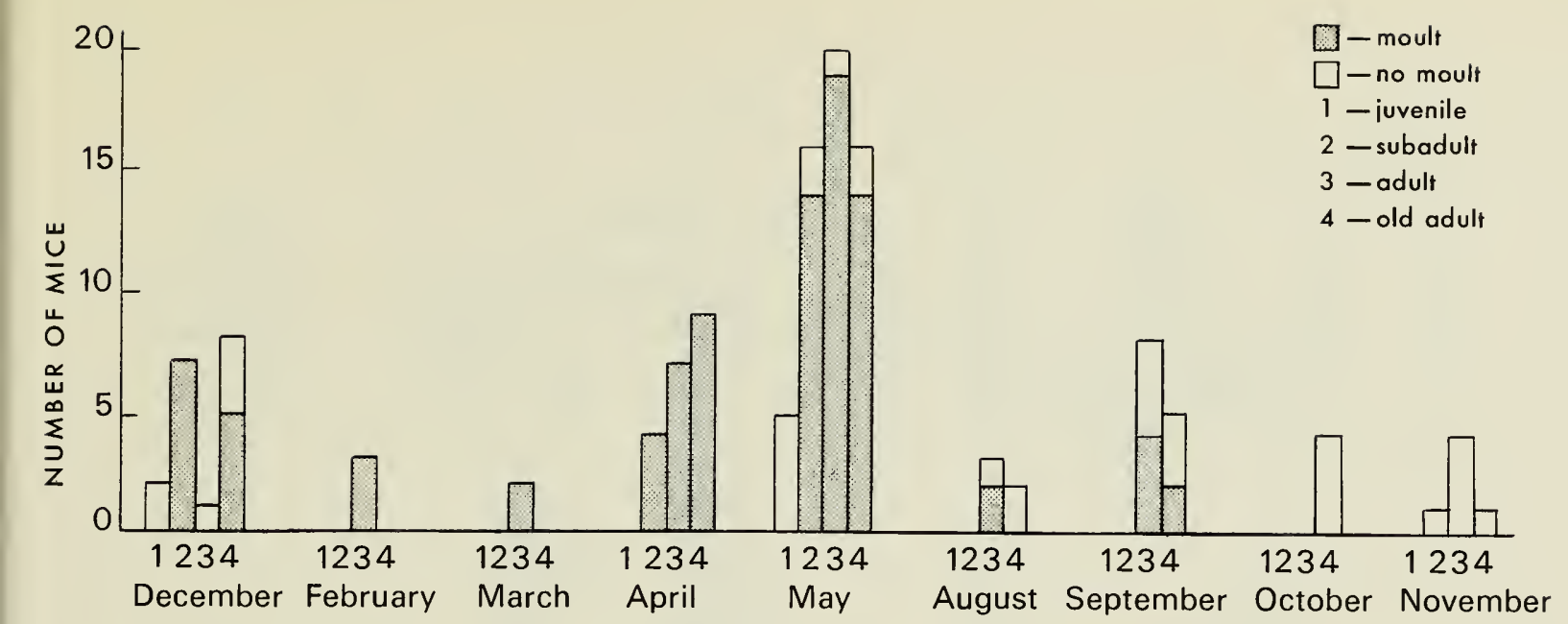

Fig. 10 Moult in Scapteromys tumidus by age classes between December 1962 and November 1963. Analysis based on 111 skins. Data from A. Langguth.

Aging was sometimes difficult in the case of certain gravid females as some individuals smaller than Class 4 showed excessive wear of the molars.

Most swamp rats collected between December 1962 and May 1963 (less January 1963 for which no specimens are available) showed some evidence of moult. Some Scapteromys collected in August and September of 1963 were also in the moult in contrast to small samples taken in October and November of that year (A. Langguth, pers. comm.). Fig. 10 summarizes data on moult available for the period December 1962 through November 1963. Specimens showing moult collected in January, June, October and November were examined in the collection of Museo de Historia Natural in Montevideo. Thus it would appear that moult is a year-round phenomenon. Peaks of moulting activity were in autumn (April and May) and again in late spring (December).

The autumn moult may require as much as a month for completion, as 12 of 20 adults $(60.0 \%)$ obtained in early April around the Laguna Merin were in early stages, whereas 21 of $52(40.4 \%)$ of the individuals collected in May were in the middle stages of moult or beyond, and 47 of 52 $(93.7 \%)$ at this time were in some stage of moult.

Pregnancy and moult, both physiologically taxing, might tend to occur at different times. However, in the sample collected in December (summer), three pregnant females were moulting. A simple $\mathrm{X}^{2}$ analysis of these data indicates that moult and pregnancy are independent $\left(\mathrm{X}^{2}=2.82\right.$ [ns], $\mathrm{df}=1$ ). Furthermore, in the autumn, all females whether pregnant or not moult into winter plumage.

None of the smaller young animals were moulting. Post-juvenile moult was noted in a number of somewhat older individuals. Growth of new hair begins at a pair of ventro-lateral centres that overlap the junction between the grayish-white venter and the blackish hair of the upper parts. Initially these areas comprise single narrow bands on each side of the body between the hind limb and forelimb, but growth soon spreads posteriorly onto the flanks, anteriorly beyond the forelimbs, and downward onto the whitish throat. Growth then proceeds from these areas onto the belly, passing ventro-medially to converge mid-ventrally. Shortly thereafter, waves of 

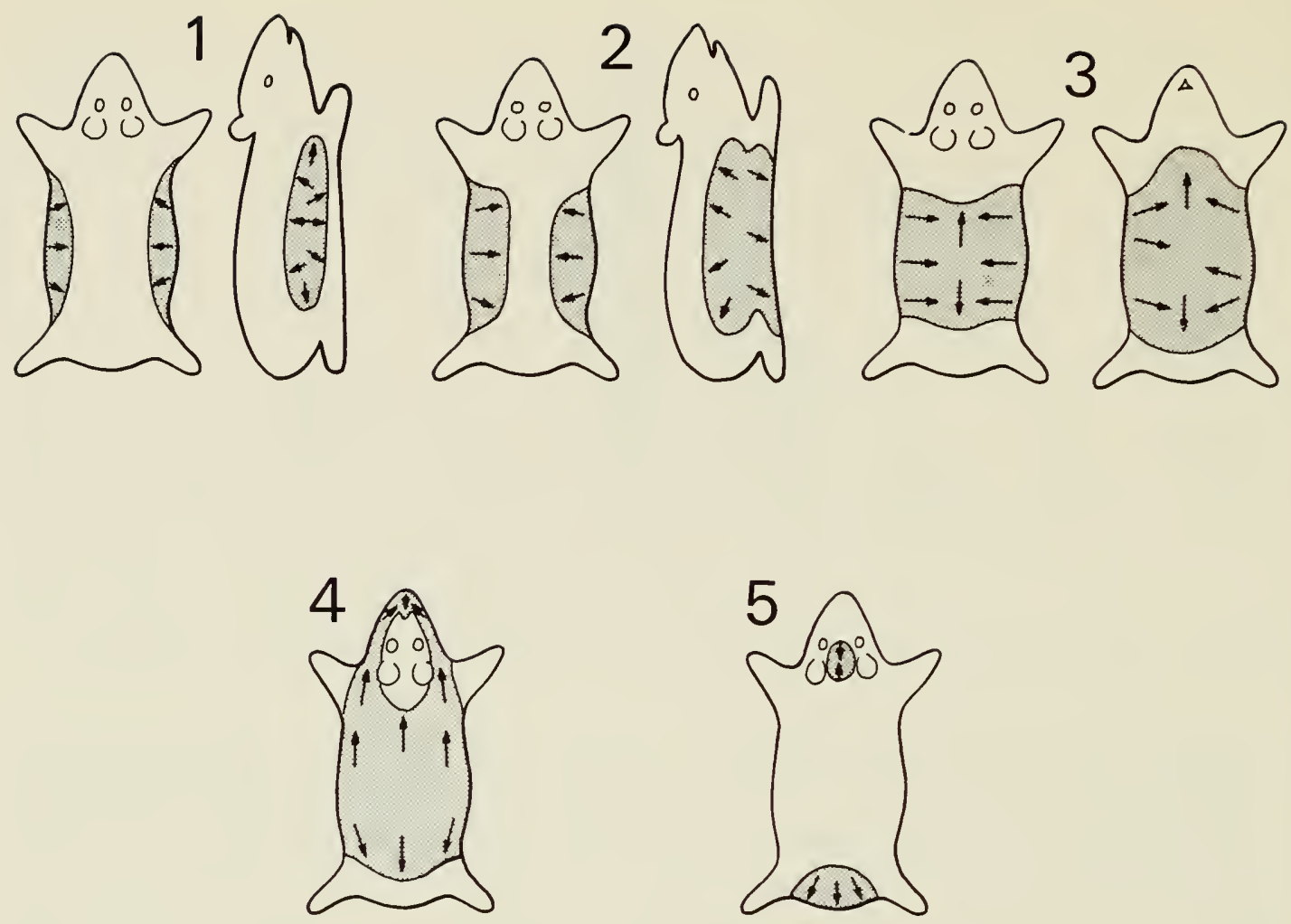

Fig. 11 The sequence of post-juvenile moult in Scapteromys tumidus as shown in dorsal and lateral exterior views $(1,2)$, dorsal and ventral views $(3)$ and dorsal views $(4,5)$.

moult that have been spreading up the sides onto the back fuse mid-dorsally forming a "saddle" stage. At this time growth has spread anteriorly on the belly and soon covers the entire throat region. Also the postero-ventral growth appears to be proceeding more slowly. When moult on the venter is complete, the grayish-white juvenile hairs have been replaced by the yellowish-white hairs characteristic of adults.

Apparently, dorsal moult lags behind that on the ventral surface. After the formation of the "saddle" stage, growth of new hair proceeds both anteriorly and posteriorly from the "saddle," but more rapidly toward the head. At the same time the lateral zones of growth have progressed anteriorly and then upward toward the mid-line, fusing on the tip of the muzzle. From this place, moult spreads posteriorly to a zone between the ears, where it converges with the wave from the dorsal surface of the thorax. The postjuvenile moult, in its terminal stages, shows moult in a narrow arc above the tail and in a patch on the crown. The sequence of moult just described is shown in Fig. 11.

Adults undergo moult resembling the post-juvenile pattern, except that additional growth centres may be present (Fig. 12). The lateral growth centres may fuse anteriorly on the dorsal mid-line in the shoulder region and shortly thereafter fuse posteriorly entrapping briefly a zone of old fur. This contrasts with the "saddle" usually developed in the post-juvenile moult.

Moult in old adults follows no apparent pattern. In fact, moult in the oldest individuals may be initiated at about the same time at a number of scattered sites (Fig. 13). 

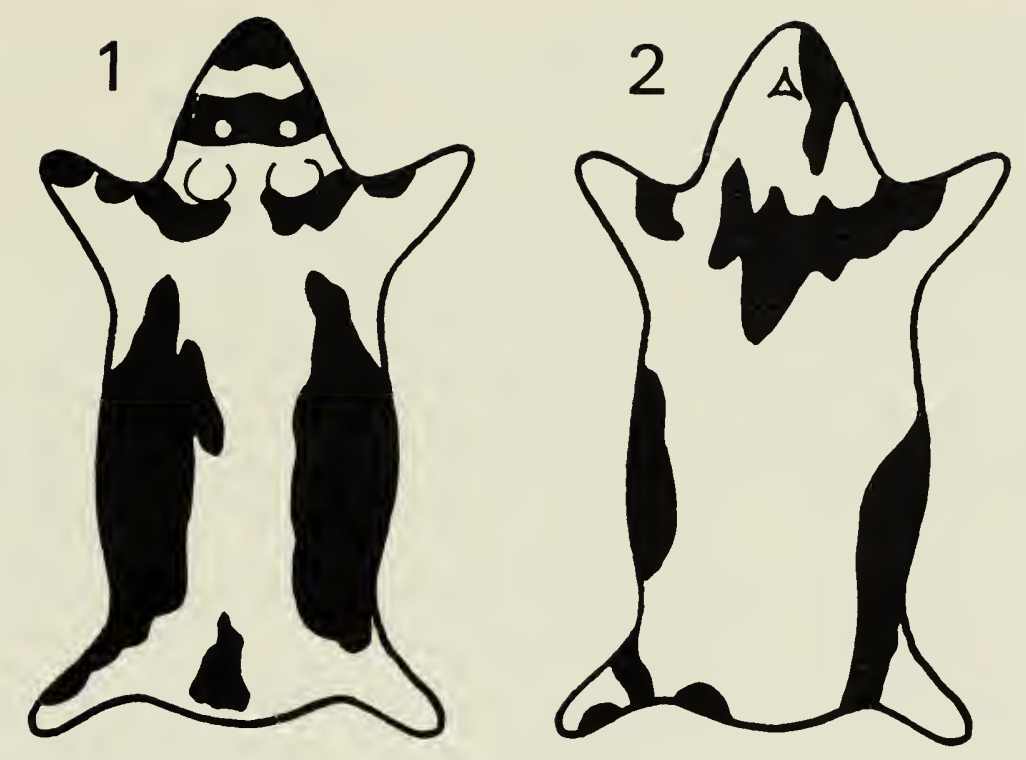

Fig. 12 Autumnal moult in an adult Scapteromys tumidus (, , AMNH 206321 ) as demonstrated by the internal pattern of melanin deposition on the dorsal (1) and ventral (2) surfaces.
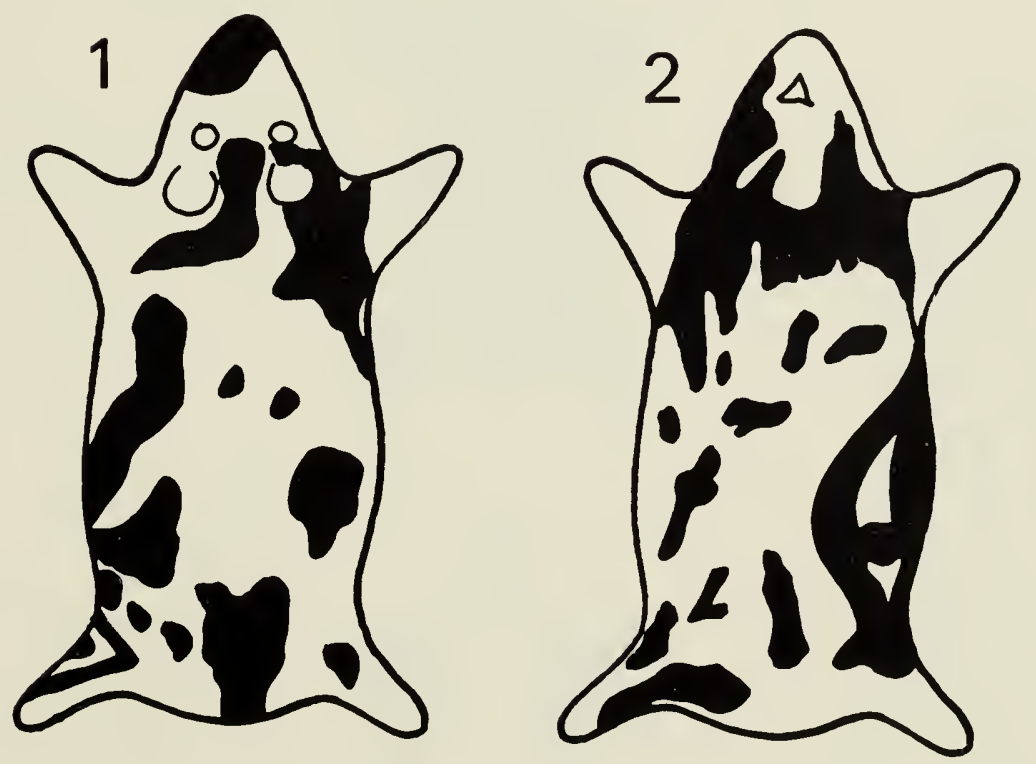

Fig. 13 Autumnal moult in an old adult Scapteromys tumidus ( ô, $A M N H$ 206267) as demonstrated by the internal pattern of melanin deposition on the dorsal (1) and ventral (2) surfaces. 


\section{Calomys laucha laucha (Desmarest)}

Vesper mouse, laucha

Specimens: Total 15; Lavalleja, $12 \mathrm{~km}$ WSW Zapicán, 7 ○ొ $\sigma^{7}, 6$ 우; Tacuarembó, 40 km NW Tacuarembó, ơ7; Treinta y Tres, 16 km SSW Boca del Río Tacuarí, o.

Ecology. Sanborn (1929:157) obtained three of these mice in four months of collecting in Uruguay. The laucha experiences periodic dramatic population increases (ratadas; Hershkovitz, 1962:45); thus our meagre sample may reflect a low ebb in the population cycle. The laucha is usually found in open grassland, rocky hillsides and edge situations but is also taken occasionally in the vicinity of marshes and swamps. Dwellings and outbuildings are likewise frequented (Hershkovitz, 1962:41). We often saw Calomys laucha at night in overgrazed rocky pasture. Reithrodon physodes was the typical associate in such places.

Calomys laucha does not make runways and rarely utilizes those of other species. Nests have been found under boards and rocks, in crevices in the ground and even in trees, often high above the ground (Massoia, 1961: 120). These mice have even sought refuge in dried skulls of livestock plentiful in the rangeland (Vaz Ferreira, 1960:67).

Calomys laucha climbs well and on the ground often hops on its hind legs in the manner of Dipodomys (Massoia, 1961:126). A female (AMNH 206345 ), caught at night by hand in overgrazed pasture, alternated between hopping in a zig-zag course and crouching motionlessly to avoid capture.
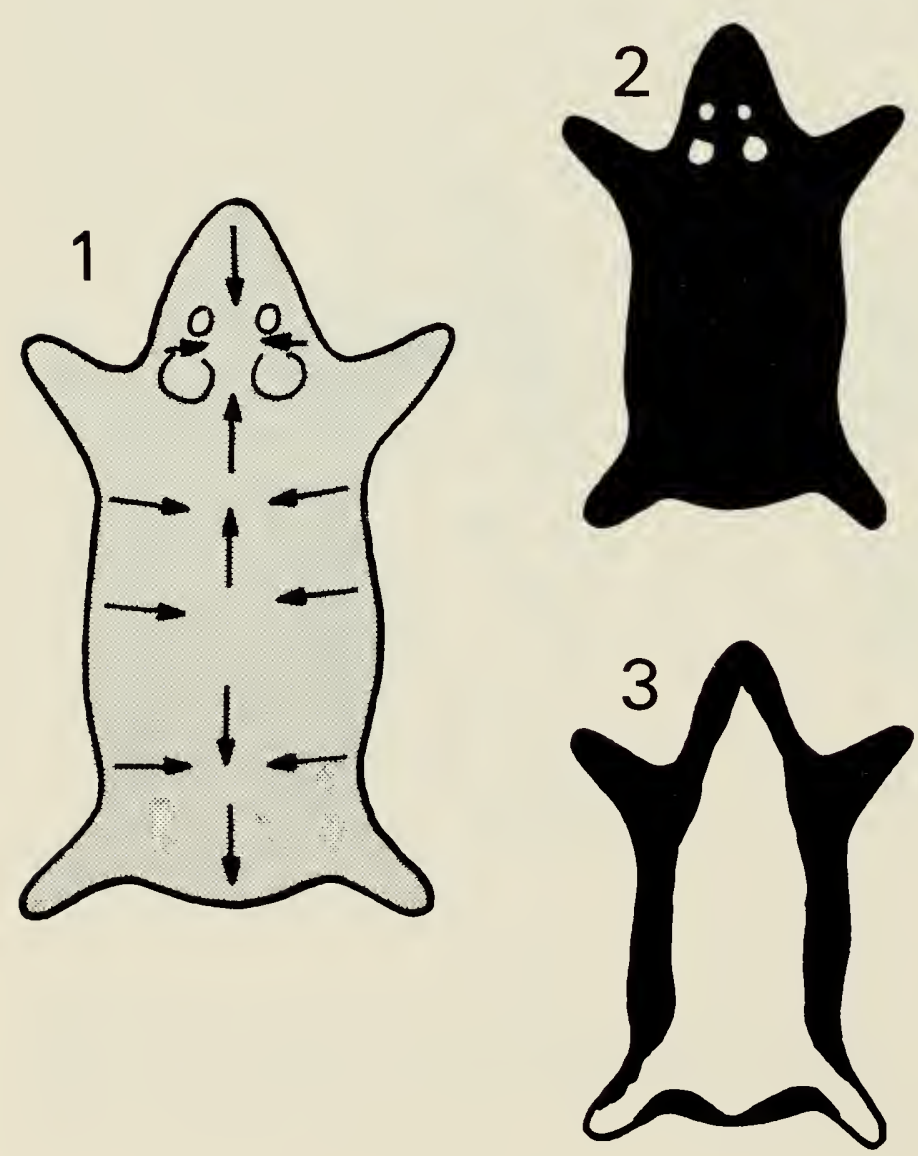

Fig. 14

Advanced autumnal moult in Calomys laucha ( ô, AMNH 206338). Diagram 1 shows exterior growth of hair with the arrows indicating direction. The smaller diagrams show corresponding interior melanin deposition dorsally (2) and ventrally (3). 
Food Habits. The laucha is predominantly herbivorous, but the stomach of one individual (AMNH 206336) contained unidentified beetle fragments.

Breeding. A female (AMNH 206345), taken 28 March 1963 in Treinta y Tres, contained four embryos $(\mathrm{CR}=10 \mathrm{~mm})$. Six females taken 28 April in Lavalleja had four to eight embryos (average six) measuring $C R=1-10$ $\mathrm{mm}$. The total of seven females had 24 embryos in the right uterine horn and 18 in the left. Testicular biopsies demonstrated that scrotal testes measuring $6 \times 4 \mathrm{~mm}$ contained abundant mature sperm. Males in breeding condition were obtained on 5 February and 28 April 1963. These data suggest that in Uruguay in summer and autumn, the breeding season of Calomys laucha is protracted. The gestation period has been calculated at 25 days (Hershkovitz, 1962:148).

Moult. Hershkovitz (1962:147) suggested that moult in this species is seasonal. Examples taken in early February and late March were not in the moult. The mouse obtained in February was in worn summer pelage. The 12 mice obtained in late April were in approximately the same advanced stage of autumn moult (Fig. 14).

Although extensive delineation of moult progression was difficult, the moult basically resembled the pattern of other Uruguayan cricetines. The April specimens demonstrated extensive moult on the dorsum. Moult spreads from lateral growth centres toward the dorsal and ventral midlines. After convergence at the mid-dorsum, hair replacement apparently proceeds rapidly posteriorly and also anteriorly to a place between the ears, where forward moving moult converges with growth sweeping posteriorly and also anteriorly from the tip of the muzzle.

\section{Reithrodon physodes physodes Olfers}

Coney rat, rata conejo

Specimens: Total 16; Artigas, 6 km NNW Belén, क; Cerro Largo, 10 km NW Paso del Dragón, ơ ; Río Negro, Arroyo Negro, 15 km S Paysandú, 4 우 ; Rocha, $22 \mathrm{~km}$ SE Lascano, $2 \sigma^{x} \sigma^{x}$, ; Soriano, $3 \mathrm{~km}$ E Cardona,

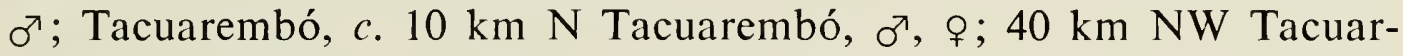
embó, 2 우; Treinta y Tres, Río Olimar Chico, 25 km WSW Treinta y Tres, $2 \sigma^{7} \sigma^{7}$.

The coney rat, Reithrodon physodes, is one of three sigmodont rodents occurring in Uruguay and the only cricetine restricted to grassland. Only 16 individuals were obtained by us in six months, most by shooting at night. Sanborn (1929:158) found coney rats widespread but uncommon. This mouse is an ecological equivalent of the hares (Lepus) of the temperate grasslands of North America, but resembles both rabbits (Sylvilagus) and the pika (Ochotona princeps) in various aspects of behaviour.

Ecology. Reithrodon physodes is usually found in overgrazed pasture, among rocky outcrops or on well-drained slopes with scanty vegetation. Dominant plants in typical Reithrodon habitat are crab grass (Digitaria sanguinalis); Bermuda grass (Cynodon dactylon); macachin (Oxalis sp.); chirca (Eupatorium buniifolium); and Baccharis melastomaefolia. In Rocha coney rats 
lived in a marshy area in a stone wall built on slightly higher ground. This stone wall extended through a frequently inundated part of the marsh and provided a permanently dry refuge. Reithrodon physodes has also been taken in wheatfields and along the sandy beaches of the coast (Sanborn, 1929:158). Coney rats dig burrows in soil varying from sandy to hardbaked clay, or utilize with or without modification abandoned burrows of Dasypus hybridus and other fossorial mammals or natural crevices and holes among rocks. Open grassland or sheltered sites beneath rocks may be excavated. In Artigas this mouse has been found living in cracks and crevices in the sun-baked mud of a road bed (Praderi and Luzardo, 1958:30).

The nearness of burrows to each other suggests that the coney rat may be variously gregarious or solitary. A colony was found in an overgrazed pasture on the western slope of a low hill on the Estancia Santa Elisa in Río Negro. The burrow entrances averaged $5 \mathrm{~cm}$ in diameter. From each a passageway descended vertically an average of $25 \mathrm{~cm}$, at which depth the tunnels became level and followed a course parallel to the surface. Active systems were marked by fresh cuttings and droppings near the entrances. Conspicuous plants in the vicinity of the burrows were chirca, crabgrass and Oxalis sp. The crabgrass had been grazed to the root tops and the chirca growth was sparse. No burrows were traced by us at this site, but we did examine a single burrow $200 \mathrm{~m}$ north where a Reithrodon previously had been trapped. This burrow was $1 \mathrm{~m}$ in length and $18 \mathrm{~cm}$ in depth, and terminated blindly in an unlined chamber measuring $14 \times 12 \mathrm{~cm}$. The single tunnel, $5 \mathrm{~cm}$ in width, turned once near the vertical part of the passage. This may have been an escape burrow as no cuttings, nesting material, or faeces were found.

In Treinta y Tres on a rocky slope above the Río Olimar Chico several extensive burrow systems were excavated and the immediate vicinity of each studied. Individual mice not only had dug tunnels but had incorporated natural crevices under rocks and abandoned armadillo burrows into their own burrow systems. All burrows were less than $2 \mathrm{~m}$ in length and had two entrances. They were occasionally branched and tortuous, with the direction of the passageways being modified by the position of buried rocks. The burrow entrances were from 3 to $5 \mathrm{~cm}$ in diameter. The tunnels were 5 to $7 \mathrm{~cm}$ in diameter and were 10 to $25 \mathrm{~cm}$ beneath the surface. Some burrows contained central, oval chambers up to $30 \mathrm{~cm}$ in diameter. In one such chamber we found a nest platform composed of a fine dry grass, the stems of a coarser grass cut into pieces $4 \mathrm{~cm}$ in length, and down of Eupatorium buniifolium. There were no faeces in the burrows but plant debris, possibly refuse from feeding, was often found concentrated in one or two places near the entrances. Defecation sites were just outside of the entrances of the burrows or within a radius of $9 \mathrm{~m}$ from them. No distinct runways led to any of these burrows.

Predators. Few data are available about the predators of this species. A skull was found in an owl pellet in Artigas. Occasional burrows showed evidence of partial excavation, possibly by a fox. 
Behaviour. The coney rat and the laucha were the most difficult of the Uruguayan cricetines to trap. At one site in Río Negro no mice were caught in traps placed in pairs at the entrances of 36 burrows. Most Reithrodon taken were shot at night. Curiosity was often the undoing of these mice when hunted. On several occasions individuals fled into burrows when frightened, only to reappear at the entrances within a few seconds. Sometimes these animals crawled completely out of the burrows and sat up on their haunches while illuminated in the beam of a flashlight. One mouse was run down and caught by hand after a short chase, during which the animal utilized zig-zag tactics in an effort to avoid capture. However, Hershkovitz (1955:639) indicates that sigmodont rodents may be found abroad both day and night. In our experience Reithrodon physodes was strictly nocturnal; however, this may simply have reflected a low level of population coincident with our work in the country.

Food Habits. Reithrodon physodes, a pastoral rodent, has sigmodont dentition specialized for an herbivorous diet. The single-chambered stomach is somewhat sacculated in the fundic region. An enlarged caecum is present at the junction of the large and small intestines.

Grasses, other plants with tuberous rhizomes, and roots are eaten. Corms of Oxalis sp. and rhizomes and roots of Digitaria sp. appear to be favoured. Countless discarded outer coverings from Oxalis corms were found in the immediate vicinity of burrow entrances, at feeding shelters, and at specific places within burrows.

Coney rats either take food into the main burrow or feed in specific shelters away from the main burrow. In Treinta y Tres a feeding shelter was found that comprised a large flat rock beneath an overhanging embankment. The surface of the rock was littered with faeces and plant fragments. No food stores were found within the burrows.

Breeding. Only two pregnant females were collected. One (AMNH 206350) taken in January in Río Negro contained four embryos $(C R=20 \mathrm{~mm})$ and the other (AMNH 206353) taken in May had three $(C R=23 \mathrm{~mm})$. A lactating female (AMNH 206349) was shot in January also in Río Negro and another with four nestling young $(\mathrm{CR}=80 \mathrm{~mm})$ was taken 7 October 1963 in Canelones (A. Langguth, pers. comm.).

Males with enlarged scrotal testes measuring at least $8 \times 5 \mathrm{~mm}$ containing abundant mature sperm and thus thought to be capable of breeding were collected in January, March, April and May. In general, sigmodont rodents breed throughout the year (Hershkovitz, 1955:639) and the temporal distribution of the breeding data for Reithrodon in Uruguay suggests that the season is long.

Moult. One of three adults trapped by Sr. Alfredo Langguth at Tropa Vieja, Canelones, 24 October 1963, showed extensive moult. Two other individuals obtained there on that date were not moulting. Only one of 10 mice taken between January and March, a subadult female (AMNH 206348; Fig. 15) showed any significant moult. Five adult Reithrodon physodes obtained in May were in various stages of autumn moult. Among these individuals the heaviest moult was found in a pregnant female (AMNH 206353; Fig. 16). 

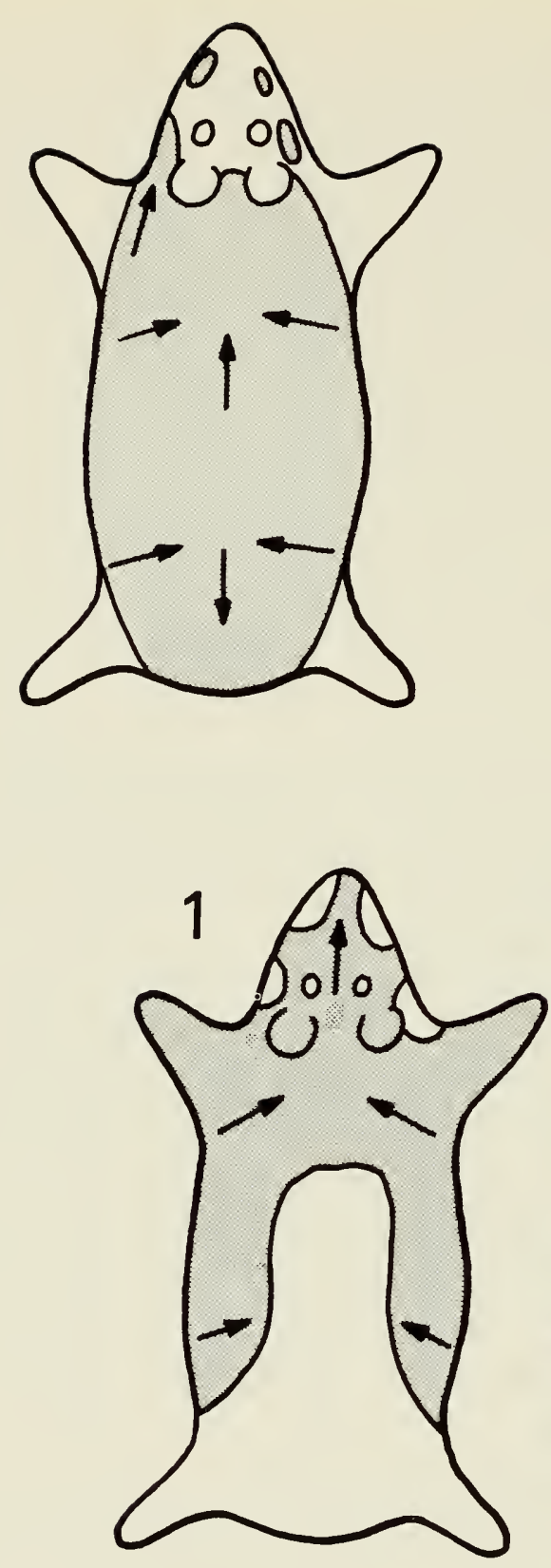

Fig. 15 Post-juvenile moult in a subadult $q$ Reithrodon physodes ( $A M N H$ 206348) as shown in a dorsal exterior view (arrows show direction of hair growth).

Fig. 16 Autumnal moult in an adult $q$ Reithrodon physodes (AMNH 206353 ) as in a dorsal exterior view (1; arrows show direction of hair growth) and the corresponding interior dorsal pattern (2) of melanin deposition. Also shown is the interior ventral pattern (3) of melanin deposition.

In the subadult individual mentioned above the ventral pattern of moult progression was not determinable. The skin of the entire dorsum posterior to the head was darkly pigmented. In this zone growth spread from the sides of the thorax toward the dorsal mid-line and fused; whence growth proceeded both toward the head and toward the rump, with the "saddle" developing just anterior to the rump. A characteristic of post-juvenile moult in this species was widespread melanin deposition in the epidermis and dermis, in contrast with melanin concentration in distinctive patterns typical of the adults examined. 


\section{Holochilus brasiliensis vulpinus (Brants)}

Brazilian marsh rat, rata de bañado

Specimens: Total 21, Canelones, Bañado de Tropa Vieja, هొ, $12 \mathrm{~km}$ WSW Zapicán, $\%$; Soriano, $3 \mathrm{~km}$ E Cardona, 8 ఠ̋ $\sigma^{7}, 7$ ㅇ; Tacuarembó, Río Negro, Isla Sanchez Chica, c. 16 km NNW San Jorgé, $2 \sigma^{7 \top} \sigma^{\top}$, ㅇ.

Ecology. This widely distributed marsh rat often has been identified as a principal species involved in irregular population eruptions (ratadas) in Brazil (Hershkovitz, 1955), Guyana (Twigg, 1962), and Argentina (Llanos, 1944). No ratadas have been recorded in Uruguay. However, irregular population fluctuations may occur. Sanborn (1929:158) considered this species common in southern Uruguay, whereas in the same general area a few years later Devincenzi (1935:71) regarded it as rare. During our visits to some localities in the west, especially in Soriano, this rat was found to be locally abundant. Holochilus brasiliensis has a broader ecological tolerance than $H$. magnus and often occurs in the most open limnic situations.

In extreme southern Tacuarembó the waters of the reservoir of the Río Negro have created islands by isolating tops of higher hills. On one such island, Sanchez Chica, with an area of approximately 50 hectares, three rats were obtained from 45 nests found in seven trees. Conspicuous vegetation on the island was crab grass (Digitaria sanguinalis), with scattered clumps of taller grasses (Andropogon sp., Paspalum sp.) and open thorn woodland dominated by Scutia buxifolia, Acacia caven, and Xilosoma warburgi. A small flock of sheep had heavily grazed the shorter grasses.

In Soriano Holochilus brasiliensis was obtained in the vicinity of a small stream. Reeds and Eryngium sp. were found on the banks, and Eichhornia sp. covered part of the surface of the water. Narrow passages through the shorter emergent plants gave evidence of Holochilus brasiliensis activity.

Holochilus brasiliensis constructs ovoid nests of leaves, sticks and grasses, averaging $22 \times 27 \mathrm{~cm}$ in diameter. Nests examined on Sanchez Chica Island were 2 to $3 \mathrm{~m}$ above the ground in terminal forks of branches and among tangles of vines growing in the trees Scutia buxifolia and Xilosoma warburgi. The unlined nests were made of sticks and leaves of these trees. Nests lined with fine plant material distinct from an outer shell of coarser plant parts have been described (Twigg, 1962:371).

On Sanchez Chica as many as 11 nests, often only a metre apart, were found in a single tree. Three of 20 nests contained one rat apiece. Marsh rats have been reported to drop to the ground when the nest is disturbed (Twigg, 1962:371) but in my experience agilely climbed higher in the trees. Since most of the trees with nests were more than $20 \mathrm{~m}$ from the water's edge, and cover was lacking between them and the water, it is understandable why the rats remained in the trees when disturbed.

Food Habits. Holochilus brasiliensis possesses high-crowned molars with a complex occlusal surface that facilitates grinding of plant materials, and the finely macerated plant material steeps in an enormous caecum. The caecum from an adult male (AMNH 206385) measured $67.8 \mathrm{~mm}$ in length. 
Although we found that the diet of Holochilus brasiliensis consists primarily of the more tender parts of aquatic, riparian and domestic plants as rice and cane, Twigg (1962:369) reported finding a small percentage of remains of snails and beetles in stomachs.

Breeding. Two of five adult females taken in Soriano in late May were breeding. One female (AMNH 206374) was lactating. The other (AMNH 206369) contained four embryos measuring $C R=10 \mathrm{~mm}$. Three of five males obtained in late May in Soriano had scrotal testes measuring $15 \times 10$ $\mathrm{mm}$ or larger. The testes of the other two adult males from this place averaged 9 × $6 \mathrm{~mm}$. A pregnant female (AMNH 206391) with two developing embryos measuring $C R=14 \mathrm{~mm}$ and resorbing two embryos was shot 10 April 1963 in extreme southern Tacuarembó on Sanchez Chica Island. A male (AMNH 206390) with scrotal testes measuring $17 \times 11 \mathrm{~mm}$ was shot 10 April at the same locality. The presence of a significant proportion of non-breeding adults among the May collected sample suggests a reduction in breeding activity associated with the onset of winter.

Moult. Only three of 14 individuals preserved as study skins available for April and May were not moulting. A juvenile (AMNH 206367) taken April 26 showed no moult. Two apparent subadults less than $310 \mathrm{~mm}$ in length demonstrated formation of a "saddle-back" condition. Typically, hair grew both toward the mid-line and anteriorly and posteriorly from the mid-dorsum. On the tip of the muzzle, zones progressing laterally turned toward the mid-line and growth then progressed posteriorly. Young adults between $350 \mathrm{~mm}$ and $400 \mathrm{~mm}$ in total length had parallel latero-dorsal growth centres from which hair replacement was progressing upward toward a zone of convergence on the mid-dorsum. Older (larger) adults showed several parallel dorsal and lateral growth centres (Fig. 17).

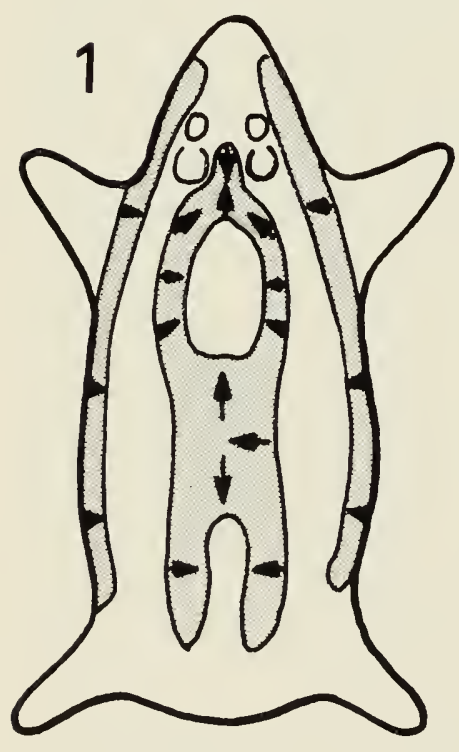

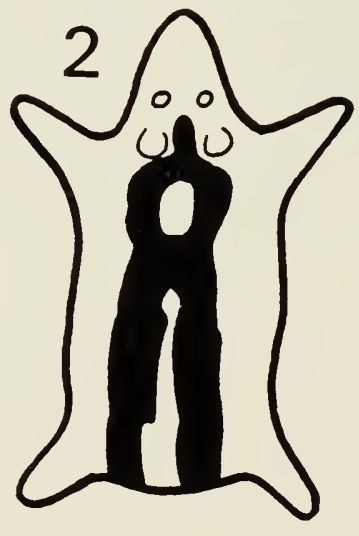

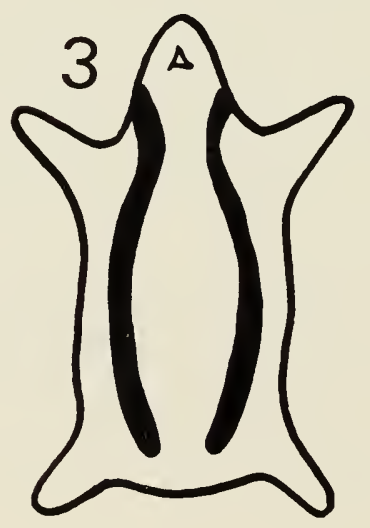

Fig. 17

Autumnal moult in an adult Holochilus brasiliensis ( ô, $A M N H$ 206390). Shown is a dorsal exterior view (1) in which arrows indicate the direction of hair growth in the region of active moult. Also shown are the corresponding views of melanin deposition on the interior dorsal (2) and ventral (3) surfaces. 


\section{Holochilus magnus Hershkovitz \\ Hershkovitz's marsh rat, rata de bañado grande}

Specimens: Total 11; Canelones, Bañado de Tropa Vieja, 2 ఠ $\sigma^{\top}$, ; Soriano, $3 \mathrm{~km}$ E Cardona, $2 \sigma^{\top} \sigma^{\top}, 4$ ㅇ; Treinta y Tres, Río Olimar Chico, $25 \mathrm{~km}$ WSW Treinta y Tres, ơ

This large cricetine, taken by C. C. Sanborn in Uruguay in 1926-27, was undetected among a series of specimens identified as Holochilus brasiliensis until its status as a distinct species was recognized by Hershkovitz (1955). The distribution of $H$. magnus still is poorly known. In Uruguay it is seemingly less abundant than $H$. brasiliensis.

Ecology. Holochilus magnus was taken in Treinta y Tres along a stream 90 $\mathrm{cm}$ wide, $15 \mathrm{~cm}$ deep and with banks $180 \mathrm{~cm}$ high. Low thorn woodland with a c'osed canopy grew to the edge of the stream. The understory consisted of tall grasses and ferns with fronds $120 \mathrm{~cm}$ in length, many of which overhung the stream. In Soriano several rats were obtained where tall bunch grass, reeds and Eryngium sp. grew profusely along a stream $1 \mathrm{~m}$ in width. Scapteromys tumidus and $H$. brasiliensis were also taken at this locality, but the latter was found in vegetation less dense that that preferred by $H$. magnus. Holochilus magnus was also obtained deep within the extensive Bañado of Tropa Vieja in Canelones.

Parasites. A female nematode (Capillaria sp.) containing numerous eggs was removed from the caecum of a male H. magnus (AMNH 206381) taken in Soriano on 25 May 1963.

Food Habits. The dentition of Holochilus magnus is more primitive than that of $H$. brasiliensis, and the molars are transitional between the "browsingcrushing and specialized grazing types" (Hershkovitz, 1955:654). Any differences in food preference existing between these two marsh rats are not readily apparent.

Stomachs examined contained primarily macerated greenish plant material. Hershkovitz $(1955: 654)$ has suggested that Holochilus magnus might have been the mollusc-eating rat mentioned by Burmeister (1879:211-212). The only invertebrate remains found by us were of a spider and a cricket (Gryllidae), and invertebrates comprised less than $5 \%$ of the total contents of three stomachs examined.

Breeding. A lactating female (AMNH 206392) with three fresh placental scars was obtained 12 April 1963, in Treinta y Tres. Another lactating female was taken in Soriano on 25 May 1963. An adult female, taken on 10 October 1963 in Canelones, was not pregnant (A. Langguth, pers. comm.).

In males, testes measuring $19 \times 12 \mathrm{~mm}$ contained abundant mature sperm. Males in breeding condition were collected in October, November (A. Langguth, pers. comm.) and in April and May. This species appears to have a protracted breeding season in Uruguay, extending at least from midspring to early autumn. 

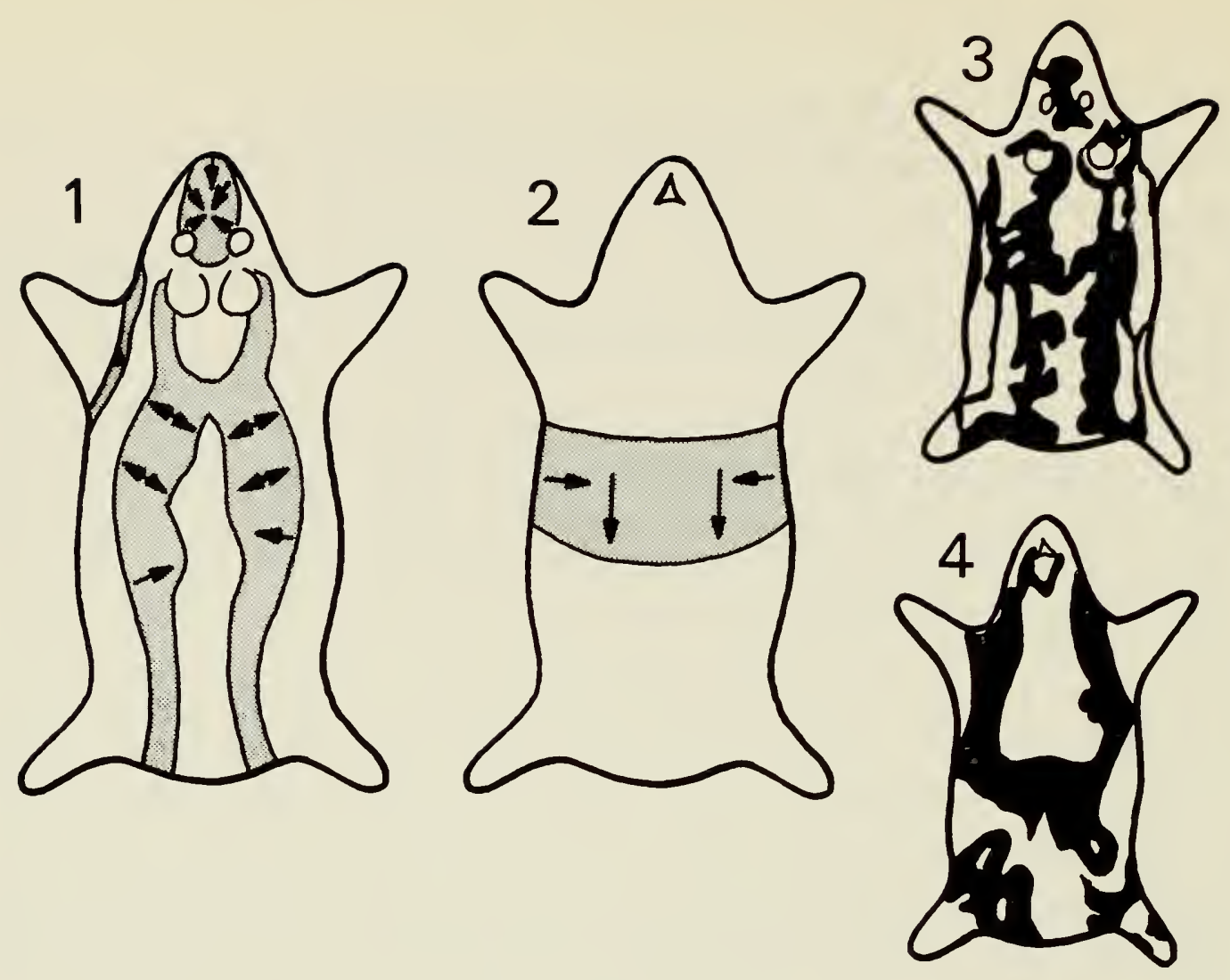

Fig. 18 Autumnal moult in an adult Holochilus magnus ( $\%, A M N H$ 206392). Shown are dorsal (1) and ventral (2) exterior views (arrows indicate direction of hair growth) and corresponding interior dorsal (3) and ventral (4) patterns of melanin deposition.

Moult. One juvenile (AMNH 206366) and two subadults (AMNH 206364, AMNH 206365) were obtained in December and January and the pelage was short and worn in all three. On the backs of the subadults were small patches of moult.

Three of five adults caught in April and May were in moult, apparently developing from several centres on the dorsum and on the venter. The internal pattern of pigment deposition closely resembled that of $H$. brasiliensis. Parallel bands from which growth proceeded both upward toward the midline and downward toward the sides of the body anteriorly and posteriorly were characteristic (Fig. 18).

\section{Mus musculus ssp. Linnaeus}

House mouse, minero

Specimens: Total 9; Lavalleja, 12 km WSW Zapicán, ; Maldonado, 17 $\mathrm{km}$ NE Aiguá, $3 \sigma^{7} \sigma^{x}, 2$ \% , ? sex; Soriano, $3 \mathrm{~km}$ E Cardona, $\sigma^{x}$; Río Negro, Arroyo Negro, $15 \mathrm{~km} \mathrm{~S}$ Paysandú, $\sigma^{7}$.

House mice have long been common around estancia buildings and in towns in Uruguay (Arechavaleta, 1887:419; Aplin, 1894:308; Sanborn, 1929:161). We caught one by hand in a granary in Río Negro on the Estancia Santa Elisa. Others were obtained under a shock of corn with Calomys laucha at an estancia in Treinta y Tres and also near farm buildings in Maldonado. 


\section{Cavia pamparum Thomas}

Guinea pig, apereá

Specimens: Total 36, Canelones, Bañado de Tropa Vieja, 2 우, ? sex; Cerro Largo, $6 \mathrm{~km}$ SE Melo, ơ; Lavalleja, $12 \mathrm{~km}$ WSW Zapicán, 3 $\sigma^{\top} \sigma^{\top}, 4$ ㅇ; Maldonado, 17 km NE Aiguá, $3 \sigma^{\top} \sigma^{\top}, 3$ 우; Barra del Arroyo Maldonado, $9 \mathrm{~km}$ ENE Punta del Este, $2 \sigma^{7} \sigma^{7}$; Rocha, $22 \mathrm{~km}$ SE Lascano, 2 $\sigma^{\top} \sigma^{\top}$, ; $10 \mathrm{~km}$ E Velázques, $\%$; Treinta y Tres, Boca del Río Tacuarí, ; $16 \mathrm{~km}$ SSW Boca del Río Tacuarí, $7 \sigma^{\pi} \sigma^{\pi}, 4$ 우우 ? sex.

Sanborn (1929:159) considered Cavia pamparum the most common rodent in Uruguay. Guinea pigs are often so abundant locally that they severely deplete grasses and other plants.

Ecology. Cavia pamparum does not excavate burrows but constructs a maze of interconnecting surface tunnels and runs, 8 to $12 \mathrm{~cm}$ in diameter. These pass through even the densest clumps of Cortaderia selloana and Eryngium sp. Earth, bared by intensive use, is exposed over much of the floor of a typical runway, but piles of the characteristic bean-shaped faecal pellets (averaging $25 \mathrm{~mm}$ in length) and plant cuttings are to be found at irregular intervals. Scapteromys tumidus, Oxymcterus rufus, Oryzomys flavescens, Akodon azarae, and Akodon obscurus make frequent use of guinea pig runways.

Cavia pamparum may forage in the open away from tunnels but typically remains close to shelter of some sort. If surprised in the open, individuals may enter burrows, natural crevices, or even holes under buildings (Aplin, 1894:309).

Guinea pigs were not attracted by bait and hence were exceedingly difficult to trap. As a consequence, traps rarely killed these rodents, but a male (AMNH 206420) weighing 367 gm was caught by the muzzle in a Museum Special trap and apparently died from the blow when the trap was sprung shut. Best trapping results were obtained with \#0 and \#1 steel traps placed within runways.

Predators. While baiting a line of snap traps in a small marsh near Melo, Thomas J. McIntyre witnessed a hunting sequence involving a grison (Galictis cuja) and a guinea pig (Cavia pamparum) on a hill adjacent to his position. As the guinea pig moved up the slope among closely cropped clumps of bunch grass a grison suddenly emerged from the edge of a patch of Eryngium sp. bordering the marsh proper. The grison, apparently searching for scent by swinging its head in an arc close to the ground, described a zig-zag course as it trotted up the hill. When the fresh trail of the guinea pig was crossed the grison quickened its pace and began to move in the direction of the potential prey. At this juncture neither the grison nor the Cavia had caught sight of one another. Then the grison, preoccupied with tracking, actually collided with the guinea pig who then took alarm and fled. A chase began as the guinea pig, with the grison a scant $15 \mathrm{~cm}$ behind, ran farther up the hill before it turned down the slope in a looping path and raced toward the marsh. The outcome of the pursuit is not known as both animals entered the Eryngium sp. growth and were lost from view. 
In addition to the grison, foxes (Dusicyon gymnocercus, Cerdocyon thous) are important predators (Aplin, 1894:309). In Rocha on 10 May 1963, the stomach of a Bothrops alternatus (snout-vent length $1115 \mathrm{~mm}$, weight $1.5 \mathrm{~kg}$ ) contained a large Cavia pamparum which had been swallowed head first.

Cavia pamparum occasionally is hunted by gauchos for food. Sanborn (1929:159) reports that the flesh is tasty when roasted.

Food Habits. Cavia pamparum is a grassland herbivore, whose niche is similar to that of many North American microtines. The diet of this species includes a variety of plants, as Digitaria sanguinalis, Cynodon dactylon, the tender parts of the stems of the taller grasses Paspalum sp. and Cortaderia selloana and the tender basal part of the leaves of Eryngium sp. At Tropa Vieja in Canelones every plant in a patch of Eryngium sp. $50 \mathrm{~m}^{2}$ was partly eaten.

Breeding. Females with one or two embryos or with post-partum uteri were collected in March, April and May. Juveniles were trapped only in December. A male (AMNH 206406) obtained on 27 February 1963 near Melo had conspicuously vascularized scrotal testes measuring $15 \times 12 \mathrm{~mm}$ that contained abundant mature sperm in the seminiferous tubules. However, males taken in April had scrotal testes as large as $20 \times 13 \mathrm{~mm}$ that contained few or no mature sperm. Two males (AMNH 206422, 206423) collected in May had inactive testes measuring $8 \times 5 \mathrm{~mm}$ and $24 \times 14 \mathrm{~mm}$. An adult female obtained by Langguth (pers. comm.) in August of 1963 was not pregnant. This guinea pig has a protracted breeding season, beginning perhaps in early spring (September) and extending until late fall (April or May). In late autumn the testes of males become inactive.

Moult. The loosely-held guard hairs are continuously lost and replaced and moult seemingly is not well defined. However, a pregnant female (AMNH 206426) caught on 25 March 1963 had an oblong area of melanin on the interior of the skin in the interscapular region and externally a fairly extensive growth of new hair.

\section{Hydrochoerus hydrochaeris uruguayensis (C. Ameghino and Rovereto)} Carpincho, capybara

Specimens: Total 15; Canelones, Arroyo Tropa Vieja, ? sex; Cerro Largo, $20 \mathrm{~km}$ SE Melo, , ? sex; Lavalleja, Río Cebollatí, $9 \mathrm{~km}$ S Pirarajá, $3 \sigma^{\top} \sigma^{\top}, 3$ ? sex; $12 \mathrm{~km}$ W Zapicán, ? sex; Río Negro, $15 \mathrm{~km} \mathrm{~S}$ Paysandú,

? sex; Rocha, $22 \mathrm{~km} \mathrm{SE} \mathrm{Lascano,} 2$ ? sex; Treinta y Tres, $16 \mathrm{~km} \mathrm{SSW}$ Boca del Río Tacuarí, , ? sex.

The present distribution and abundance of Hydrochoerus hydrochaeris in Uruguay has been strongly affected by local hunting pressure. In relatively populous areas near Montevideo, where marshes persist and hunting is somewhat curtailed, carpinchos still commonly occur. Fresh piles of faeces were found in the marsh along the Arroyo Tropa Vieja, in Canelones. Neither the animals themselves nor sign were noted along the Arroyo Negro 
in Río Negro. In southwestern Artigas along the Río Uruguay, only two individuals were observed in 15 days, and sign were scarce. Praderi and Luzardo (1958:311) saw several swimming in the Arroyo Tres Cruces Grande in northern Artigas, but nonetheless considered Hydrochoerus hydrochaeris to be uncommon in that region. Several stretched hides were in the possession of gauchos at Infiernillo in Tacuarembó, but we found no sign there in the canyon of the Arroyo Tres Cruces. Along the Río Tacuarí, in Cerro Largo at Sierra de Vaz, capybaras were fairly common, as many as seven were seen together at one time, and fresh faeces were noted daily on both banks of this stream. In Treinta y Tres around the Laguna Merin and along the Río Olimar Chico in western Treinta y Tres, capybaras were fairly common and were seen both at night and in the daytime. Along the Río Cebollatí in Lavalleja, the riparian woodland was laced with pathways made by these animals, and several individuals were seen daily. In Durazno, at the reservoir of the Río Negro, I saw no live animals although one was shot by hunters during our visit. In Rocha at the Estancia El Sauce capybaras were not uncommon in the more extensive tracts of marsh close to camp.

Ecology. In most localities capybaras inhabited dense to open woodland near swiftly flowing or sluggish waterways but were also found, as in Rocha, in marshes where tall grasses provided cover and the surface of the water was covered by waterlilies (Eichhornia sp.). In a fairly extensive woodland along the Laguna Merin the dominant tall tree was the Humboldt willow (Salix humboldtiana) and the principal component of the understory was sarandí (Cephalanthus sp.) which grew profusely and well beyond the area dominated by the willows. The zone of sarandí was abundantly penetrated by intersecting tunnel-like runways made by capybaras, $30 \mathrm{~cm}$ or more in width and more than $38 \mathrm{~cm}$ in height. These runways were used by many other mammals, notably the foxes Dusicyon gymnocercus and Cerdocyon thous, the wildcat Felis geoffroyi, the skunk Conepatus chinga and the opossum Didelphis azarae.

Behaviour. Capybaras are primarily nocturnal in parts of Uruguay where they are hunted, but where they have been little disturbed, as along the Río Cebollatí in Lavalleja, they may be seen grazing, wallowing in mud or dozing at various times of the day. Along the Río Tacuarí in Cerro Largo, they were occasionally heard during the day. Here at the Laguna Merin they emerged at dark from the woodland to graze in the open pastureland.

Capybaras are hunted by a lone man stalking the animals from a downwind position or by several men on horseback with dogs. Hunters try to keep capybaras from reaching water, into which they readily dive and submerge. All capybaras obtained by us were shot, either in the day or jacklighted at night. A female (AMNH 206452) shot in April 1963 at the Laguna Merin, emitted yowls, whines and screams reminiscent of those of a large dog in pain.

Capybaras behave variously when approached by man, depending apparently upon whether or not the intruder has been scented. Hearing and 
vision seem relatively weak. Those that flee immediately emit a characteristic "woof." If the capybara has not fled immediately, it first stands alertly and tests the air with its nose, then begins to move slowly toward water. Sydney Anderson approached to within $30 \mathrm{~m}$ of a capybara before it fled. The female that I subsequently shot was initially approached to within $13 \mathrm{~m}$ and showed only slight alarm. Merlin Tuttle shot the first of two young capybaras, lying only $2 \mathrm{~m}$ apart and dozing in a mud wallow along the Río Cebollatí, without causing the second individual to flee. Alarm leading to flight is an individual response in most instances. One individual in a group may detect danger and dive into the water, while the others show little alarm; on other occasions all may be stimulated and take flight simultaneously.

Capybaras wallow in muddy areas along stream banks and in quiet backwaters. A wallow was found among the exposed roots of willows in a clearing in the woodland adjacent to the Laguna Merin. A wallow c. $40 \mathrm{~m}$ from the main stream of the Río Cebollatí was approached from several directions by well marked pathways, and the bank above the wallow was deeply dissected at one place as a result of intensive use.

Food habits. Capybaras are strictly herbivorous. At Sierra de Vaz in Cerro Largo, animals were seen foraging upon the shorter range grasses, especially crabgrass (Digitaria sp.), Bermuda grass (Cynodon dactylon) and Oxalis sp. Although long nocturnal treks for food have been mentioned (Aplin, 1894:30), we never knew this animal to forage more than $100 \mathrm{~m}$ from water. Foraging sites were repeatedly used, and near the Laguna Merin and at Sierra de Vaz the resident capybaras returned nightly to the same areas.

Capybaras have a long intestinal tract typical of herbivores. In the female taken in Treinta y Tres, the small intestine was $13.5 \mathrm{~m}$ in length and about $2 \mathrm{~cm}$ in diameter. The caecum which was enormously distended with macerated plant material was $80 \mathrm{~cm}$ in length and $22 \mathrm{~cm}$ across at its widest part. The colon tapered from a diameter of nearly $20 \mathrm{~cm}$ to $2 \mathrm{~cm}$ in the first metre and maintained this diameter for the remaining $3.8 \mathrm{~m}$ of its length. The distinctive oblong faecal pellets were well formed when they had reached the last metre of the colon. These pellets measuring about $25 \times 15$ $\mathrm{mm}$ are green when defecated, but in a day or two they fade to brownish green and eventually to ash gray.

Although there is no direct evidence of territorial behaviour in capybaras, deposition of faeces seems to be somewhat localized and occurs near but not within frequented runways in tang!ed vegetation or on regularly travelled paths. Specific foraging sites frequented are also near sites of extensive faecal depositions.

Breeding. Two females and six juveniles were seen together in the riparian growth along the Río Cebollatí on 13 December 1962. Herds of from seven to 15 animals of two distinct size groups were seen at several localities between December and May. Aplin (1894:312) saw a young individual not more than $30 \mathrm{~cm}$ long in the company of an adult female on 8 May in Soriano. The breeding season in Uruguay is protracted, perhaps extending for about seven months from early spring to late summer. 


\section{Myocastor coypus bonariensis (Commerson)}

Nutria

Specimens: Total 8; Río Negro, Arroyo Negro, 15 km S Paysandú, ơ , Rocha, 22 km SE Lascano, ? sex; Treinta y Tres, Boca del Río Tacuarí, 2 ? sex; 16 km SSW Boca del Río Tacuarí, ơ, 2 ? sex.

Although the nutria is protected by law in Uruguay it has long been subjected to intensive poaching, especially since the turn of the century. Aplin (1894:313) found it common along some of the larger water courses in Soriano, but by the late 1920s and early 1930s it had become rare in the more populous regions of the country (Sanborn 1929:160; Devincenzi, 1935:74-75). However, Sanborn (1929:160) indicated that nutrias were still common around the Laguna Negra in Rocha at the time of his expedition. In 1963 estancia owners told us that at one time thousands of nutrias were poached annually around the Laguna Negra, but more recently the number had dropped to a few dozen yearly. It is indeed ironic that $\mathrm{MyO}$ castor coypus is in danger of extinction throughout much of its native range in South America, yet flourishes to the point of becoming a pest where it has been introduced in the United States, Europe and Asia (U.S.S.R.).

Our records come from widespread localities in the country. Two young males were shot along the Arroyo Tres Cruces Grande in northern Artigas on 29 September 1957 (Praderi and Luzardo, 1958). Two (AMNH 206454, AMNH 206455) were taken by us in Río Negro along the Arroyo Negro. Another (AMNH 206461) was obtained in far eastern Treinta y Tres near the Laguna Merin. One was seen in a drainage ditch on 23 March 1963 in southern Cerro Largo. Sign and later a fresh skeleton were found in Rocha on the Estancia El Sauce. Merlin D. Tuttle found fresh faeces in Soriano near Cardona.

Ecology. In Uruguay the nutria inhabits large swamps and marshes dominated by Scirpus sp. and Cortaderia sp., edges of rivers and streams, manmade ponds and even drainage ditches with little surrounding vegetation. Waterways having steep banks are preferred as burrow sites. If steep banks are not available, nest platforms are built above ground among tall marsh vegetation. Such platforms were found in Rocha along an unnamed arroyo. A complex burrow system was excavated and traced in Flores by Sierra de Soriano (1960:9). Three divisions were recognized. Tunnels and passageways found among the rushes and the emergent water lilies growing in the pond led to the main entrance of the subterranean burrow in the bank. The tunnels and enlarged chambers of this part of the system extended inward $7 \mathrm{~m}$ from the water's edge and averaged $4.5 \mathrm{~cm}$ below the surface. Two openings to the surface communicated with extensive runways in vegetation which surrounded the pond. These runways widened at intervals where platforms of vegetation were present. Surface runways of nutrias frequently provide routes for other mammals as Oxmycterus rufus, Cavia pamparum, Oryzomys sp. and Conepatus chinga. 
Breeding. The subadult female from Río Negro was not pregnant. The epididymides of a male with testes measuring $32 \times 20 \mathrm{~mm}$, taken $26 \mathrm{March}$, contained mature sperm.

\section{Ctenomys torquatus Lichtenstein}

Tuco-tuco

Specimens: Total 94; Cerro Largo, $6 \mathrm{~km} \mathrm{SE} \mathrm{Melo,} 8 \sigma^{\nearrow} \sigma^{\nearrow}, 18$ \%ᄋ; 20 km SE Melo, $8 \sigma^{\nearrow} \sigma^{\nearrow}, 16$ \% ; Lavalleja, $12 \mathrm{~km}$ WSW Zapicán, 10 ๙ $\sigma^{\nearrow}$, 24 ๆ , ? sex; Maldonado, Barra del Arroyo Maldonado, 9 km ENE Punta del Este, $\%$; Tacuarembó, 15 km NW Tacuarembó, $\sigma^{7}, 4$ $\%$; 40 km NW Tacuarembó, 2 ఠフ $\sigma^{\nearrow}$, ․

Species of the hystricomorph genus Ctenomys abound in the southern half of South America. These rodents remarkably resemble North American pocket gophers (Geomys sp. and Thomomys sp.) both in morphology and in fossorial habits. Differences in burrowing do exist, however; gophers excavate with their teeth and the claws of their forefeet, pushing loosened dirt out of the burrow with their head and chest. Tuco-tucos dig with their forefeet, then sweep the dirt out of the tunnel with their hind feet. Ctenomys torquatus can close its lips behind its teeth which should make possible their use in digging, but neither Sanborn (1929:159) nor Pearson (1959:44) observed use of the incisors in burrowing.

A single species, Ctenomys torquatus, occurs in Uruguay. The results of the research of Dr. Rodolfo Talice and associates, who have studied this animal in the field and laboratory for more than ten years, have not been widely available in English and thus many of their data are incorporated below.

Ecology. Tuco-tucos were found in cultivated ground in Tacuarembó, in vacant lots within a residential district in the city of Montevideo, in stabilized dunes along the Atlantic coast in Maldonado, and in over-grazed pasture in many places. Vegetation typical of the latter habitat near Melo included: Oxalis sp.; Setaria geniculata; Digitaria sanguinalis; Aspilia sp.; Discaria longispina; and Eryngium sp. Digitaria and Oxalis sp. formed a thick turf throughout which other plants were scattered. At Sierra de Vaz clumps of the taller grass, Paspalum sp., were growing within the limits of a Ctenomys torquatus colony.

Soil composition probably limits local distribution of this mammal. Preference for sandy, rock-free soils has been noted by several authors (Devincenzi, 1935:74; Sanborn, 1929:159; Talice and Momigliano, 1954:126). This predilection was best demonstrated in upland areas in Tacuarembó, where tuco-tucos occurred in isolated pockets of sandy soil, but were absent from adjacent rockier and more compact soils. Along the banks of the Río Tacuarí at Sierra de Vaz, Ctenomys torquatus lived only in the adjacent rock-free alluvial soils. 
Tuco-tucos live in loosely organized colonies and burrow systems are generally more than $120 \mathrm{~cm}$ apart. At the surface, these burrows were characterized by the presence of a single mound of dirt $(25$ to $75 \mathrm{~cm}$ in diameter) containing faecal material and some plant cuttings. Some nearby burrow systems in the colony apparently had more than one mound although we did not excavate them to verify this. Besides the entrance associated with the mound of dirt, the three burrows examined by us had an average of seven other surface openings, each marked by an "apron" or cleared area averaging $8 \times 7 \mathrm{~cm}$. These entrances were either open or plugged, depending upon the activities of the resident tuco-tuco. Long unused entrances had plugs greater than $10 \mathrm{~cm}$ thick. In burrows in stabilized dunes in Maldonado plugs more than $60 \mathrm{~cm}$ thick blocked the entrances of some passages.

We explored in detail the burrows of a young adult male (AMNH 206466) (Fig. 19) and of an adult female (AMNH 206465) (Fig. 20). These systems consisted of an essentially straight main tunnel with several shorter lateral passages. Typically the lateral pasages either ended blindly, their ends being packed with sandy soil containing faecal pellets and plant cuttings (especially of Eryngium sp. and Digitaria sp.) or they opened to the surface at feeding sites. Both systems had a nest chamber off the main passage. In the burrow of the male this chamber was at a depth of $30 \mathrm{~cm}$, measured $18 \times 15 \mathrm{~cm}$, and contained a nest measuring $15 \times 10 \mathrm{~cm}$ made of pieces of grasses, mostly Digitaria sp., averaging $1.5 \mathrm{~cm}$ long. The nest chamber of the female measuring $27 \times 14 \mathrm{~cm}$, was completely filled with a nest composed of short grass cuttings.

The tunnels averaged $7 \mathrm{~cm}$ in diameter, but occasionally widened to 13 $\mathrm{cm}$ and nowhere exceeded $40 \mathrm{~cm}$ in depth. Ctenomys torquatus tends to dig at a uniform depth after an initial descent from any entrance. In contrast, burrows of Thomomys bottae navus depicted by Miller (1957:435) varied more in depth along their lengths and had occasional nearly vertical tunnels $1 \mathrm{~m}$ deep which ended blindly. Typically Ctenomys torquatus tunnels passed significantly beneath the depth of the root zone of plants in

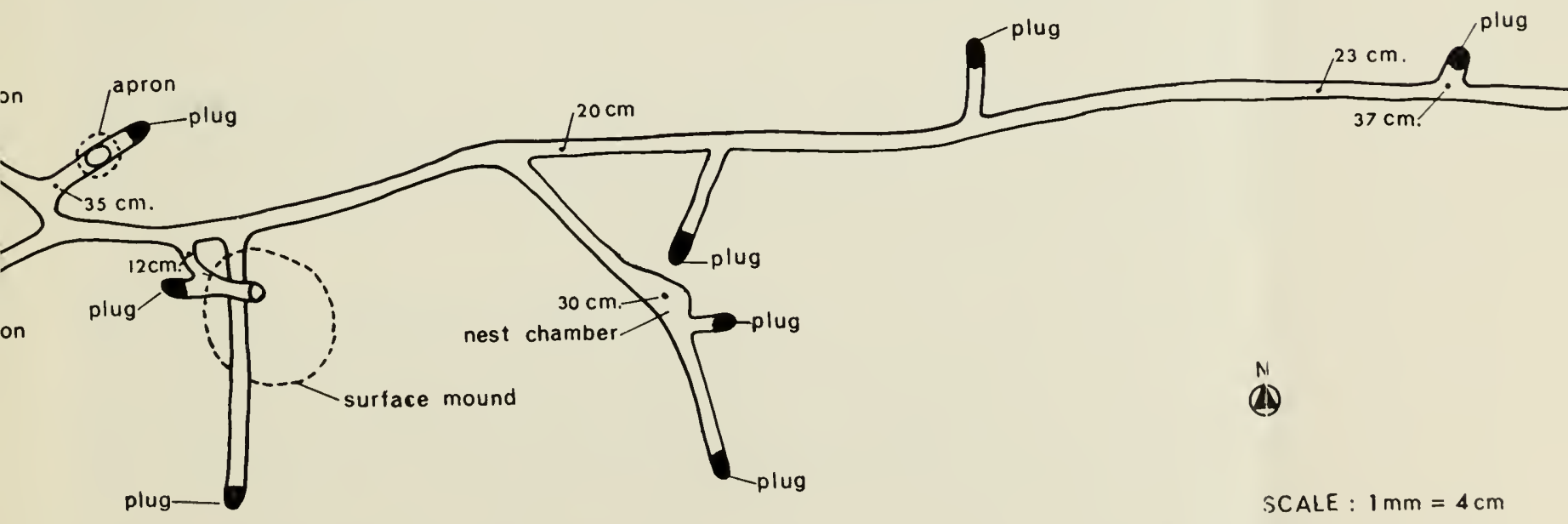

Fig. 19 The burrow system occupied by a young adult $\hat{o}$ Ctenomys torquatus (AMNH 206466; 25 February 1963; Cerro Largo, 6 km SE Melo). The nearest burrow system (that of a $q$ ) was $2 \mathrm{~m}$ to the north. Measurements refer to the depths of the floor of the passages beneath the surface. 


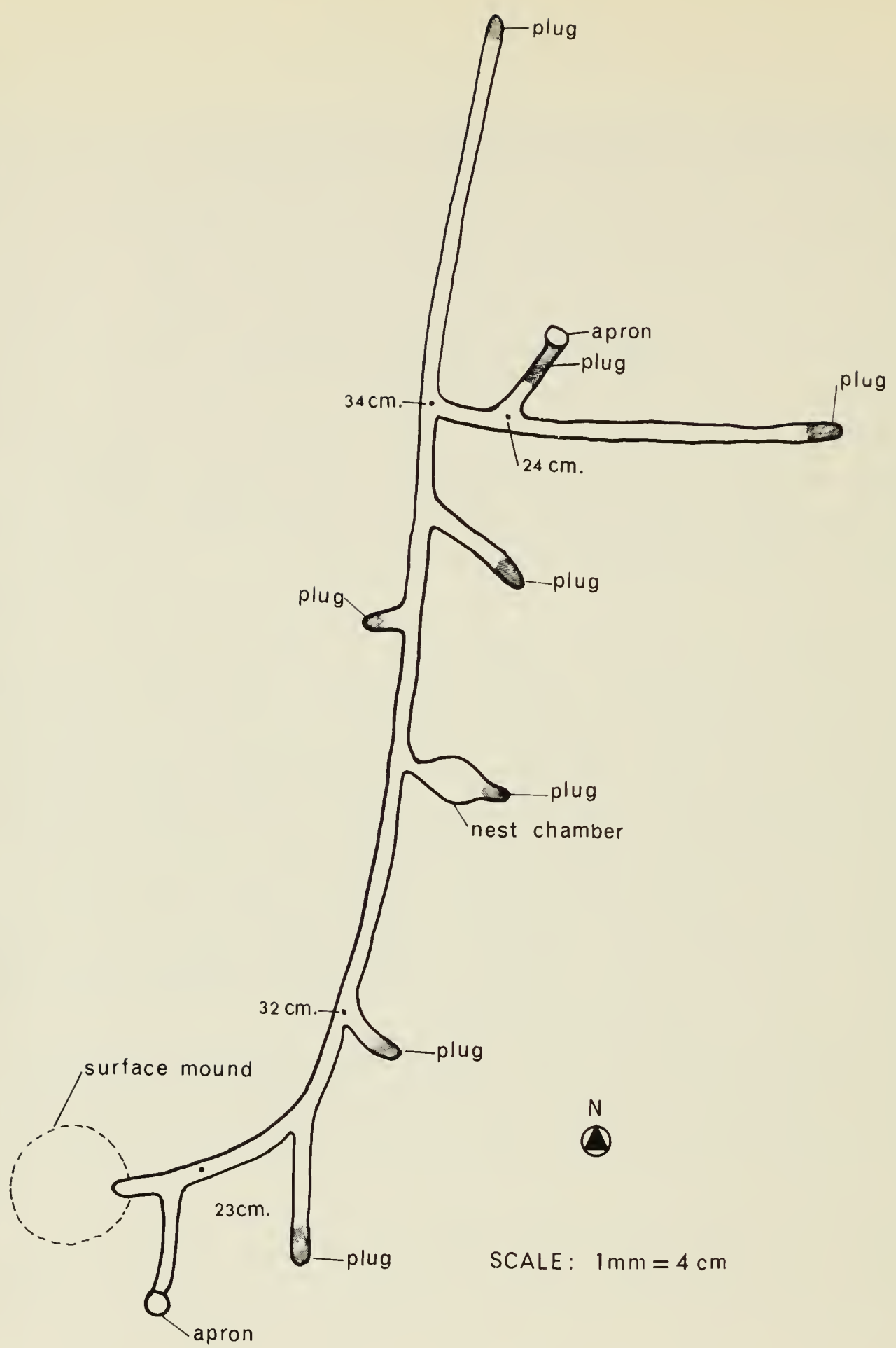

Fig. 20 The burrow system occupied by an adult $\$$ Ctenomys torquatus (AMNH 206465; 23 February 1963; Cerro Largo, $6 \mathrm{~km} \mathrm{SE} \mathrm{Melo).} \mathrm{The}$ nearest burrow system was $20 \mathrm{~m}$ northwest. Measurements refer to the depths of the floor of the passages beneath the surface.

the habitat. Dense masses of roots and tubers penetrated to an average depth of $10 \mathrm{~cm}$ with occasional roots as deep as $30 \mathrm{~cm}$ or within range of the tunnels. The burrows excavated averaged about $4 \frac{1}{2} \mathrm{~m}$ long. Dimensions of the above mentioned burrows differed little from those examined by Talice and Momigliano (1954:131) in the Departments of Montevideo and Maldonado.

The microclimate of the burrows varies little. In summer, the temperature ranges from $19^{\circ} \mathrm{C}$ to $21^{\circ} \mathrm{C}$ and the humidity from $78.8 \%$ to $81.8 \%$ at a depth of $25 \mathrm{~cm}$ (Talice and Momigliano, 1954:129). 
Eighty burrow systems were noted in an area of seven hectares near our campsite outside of Melo. An area of three hectares at this same locality yielded 26 Ctenomys torquatus. At Sierra de Vaz, 24 tuco-tucos were trapped in an area $30 \times 100 \mathrm{~m}$. By comparison, Pearson (1959:35) removed 28 Ctenomys peruanus from a census area $82 \mathrm{~m}$ square. The number of tuco-tucos per unit area is, in part, a function of abundance of preferred food plants. In one hectare in stabilized dunes at Maldonado only four burrows were counted.

All but one tuco-tuco were caught in Macabee traps placed within the entrances of the burrows. Most were caught by the hind parts, probably as a result of attempts to sweep unfamiliar objects out of the burrow with their hind feet, as described by Pearson (1959:15). In the afternoon they were sometimes caught two minutes after a trap had been emplaced. One individual succeeded in plugging its burrow behind the trap on seven successive occasions before capture. Trapping success was high, and virtually every active system eventually yielded a specimen.

Behaviour. Ctenomys torquatus is diurnal in surface activity. At all colonies investigated maximum surface activity occurred between 1:00 p.m. and 4:00 p.m. A captive individual was active daily between 7:00 a.m. and 6:00 p.m., with a period of quiescence between 11:00 a.m. and 1:00 p.m. In the field individuals were frequently seen foraging or sitting quietly at burrow entrances for periods of up to 15 minutes during the hours of maximum activity.

Tuco-tucos are purportedly awkward above ground (Pearson, 1954:44). Sanborn (1929:159) reported that individuals found at a distance from a burrow entrance became disoriented and dashed erratically about seeking shelter when frightened. Tuco-tucos were never observed to move more than two-thirds of the way out of a burrow entrance when foraging or resting, a precaution tending to reduce danger from predators. When released for brief periods, captive individuals were less agile and slower than, for example, terrestrial cricetines but certainly did not seem exceptionally awkward. Talice et al. (1959:457) noted that Ctenomys torquatus walked normally for a quadruped, moving in a rapid and sinuous fashion, pausing periodically to look about, but found it to be a poor swimmer.

By deliberate stalking, it was possible on several occasions to crawl from a position downwind to within $3 \mathrm{~m}$ of a tuco-tuco foraging at the entrance to its burrow. When we walked over the burrow systems tuco-tucos active at the surface seemingly detected our presence downwind at a distance of $20 \mathrm{~m}$ and subsequently disappeared from sight.

We only distinguished three vocalizations. The repetitive syllabic call, the basis of the vernacular name tuco-tuco, was uttered by animals from within the entrances of burrows. Not all species of Ctenomys give this type of call but among those that do, significant differences in tonal qualities are recognizable. In Perú, Pearson (1959:30) found that only Ctenomys peruanus of three species studied had a conspicuous bubbling and melodious vocalization which reminded him of the song of the bobolink (Dolichonyx oryzivorus). 
To me the primary vocalization of Ctenomys torquatus was not melodious but rather guttural, gravelly and at times like the sound produced by rubbing together two pieces of coarse sand paper. Talice et al. (1959:457) described the call as being composed of dry sounds, solemn, more or less measured and difficult to locate in the field. The call consists of a repetition of the syllable tloc. In two minutes of monitoring I counted 23 repetitions in the first minute and 29 in the second. On quiet days calls were audible up to a distance of about $30 \mathrm{~m}$.

In captivity a series of pig-like grunts, uttered in rapid succession, was noted in times of mild excitement. Talice et al. (1959:457) report similar vocalizations in captive animals. Grunts, and squeals were uttered by individuals caught in Macabee traps whenever we pulled a caught individual to the surface.

Food Habits. Ctenomys torquatus is strictly an herbivore and possesses hypsodont, continuously growing molars with complex occlusal surfaces adapted to crush and grind coarse vegetation. Pearson (1959:45) noted that Peruvian species ate roots, stems, leaves, blossoms and fruits of a wide variety of plants. $C$. peruanus ate some while at the surface, but $C$. opimus cut food and retreated into the burrow. $C$. torquatus feeds primarily on the surface and eats entire plants in the vicinity of an entrance. A semicircular area or "apron" some $8 \times 7 \mathrm{~cm}$ that typically cuts into the root zone to a depth of $2 \mathrm{~cm}$ is formed. Some cuttings were found within the burrows, but no distinct food stores were located, nor was there evidence of extensive subterranean feeding. Talice and Momigliano (1954:131) indicate that food items presented to captive animals were often hoarded.

One of our captive tuco-tucos, when offered rhizomes of Digitaria sp., sat on its haunches, held the stems alternately with one and then both forepaws and slowly pushed the plant parts into its mouth as it chewed. Carrot slices were manipulated in a similar fashion.

In the wild, tuco-tucos eat tender parts of the leaves of Eryngium sp., entire plants of Digitaria sanguinalis, and corms of Oxalis sp. Talice and Momigliano (1954:131) report consumption in the wild of the following piants: Solidago chilensis, Androtrichum trigynum, Comphrena perennis, Aster montevidensis, Oenothera indecora, Cynodon dactylon, Sporobolus poiretu, Cyperus cayennensis, Anthemis mixta and Cenchrus tribuloides.

Breeding. Ctenomys torquatus is monoestrous. Pregnant females with two or three embryos are found from September through January. The gestation period in this species is approximately 105 days (Talice et al., 1959:459). None collected by us between February and May was breeding. Histological analysis of biopsies of males with testes averaging $8 \times 4 \mathrm{~mm}$ indicated breeding inactivity.

Moult. Tuco-tucos were trapped between early February and mid-May at four localities in eastern and southern Uruguay, and most showed some moult. In February and March moult in adults and in young of the year was patchy and of slight extent and small growth centres developed separately on the head, behind the shoulders, and on the rump. Moult was less 

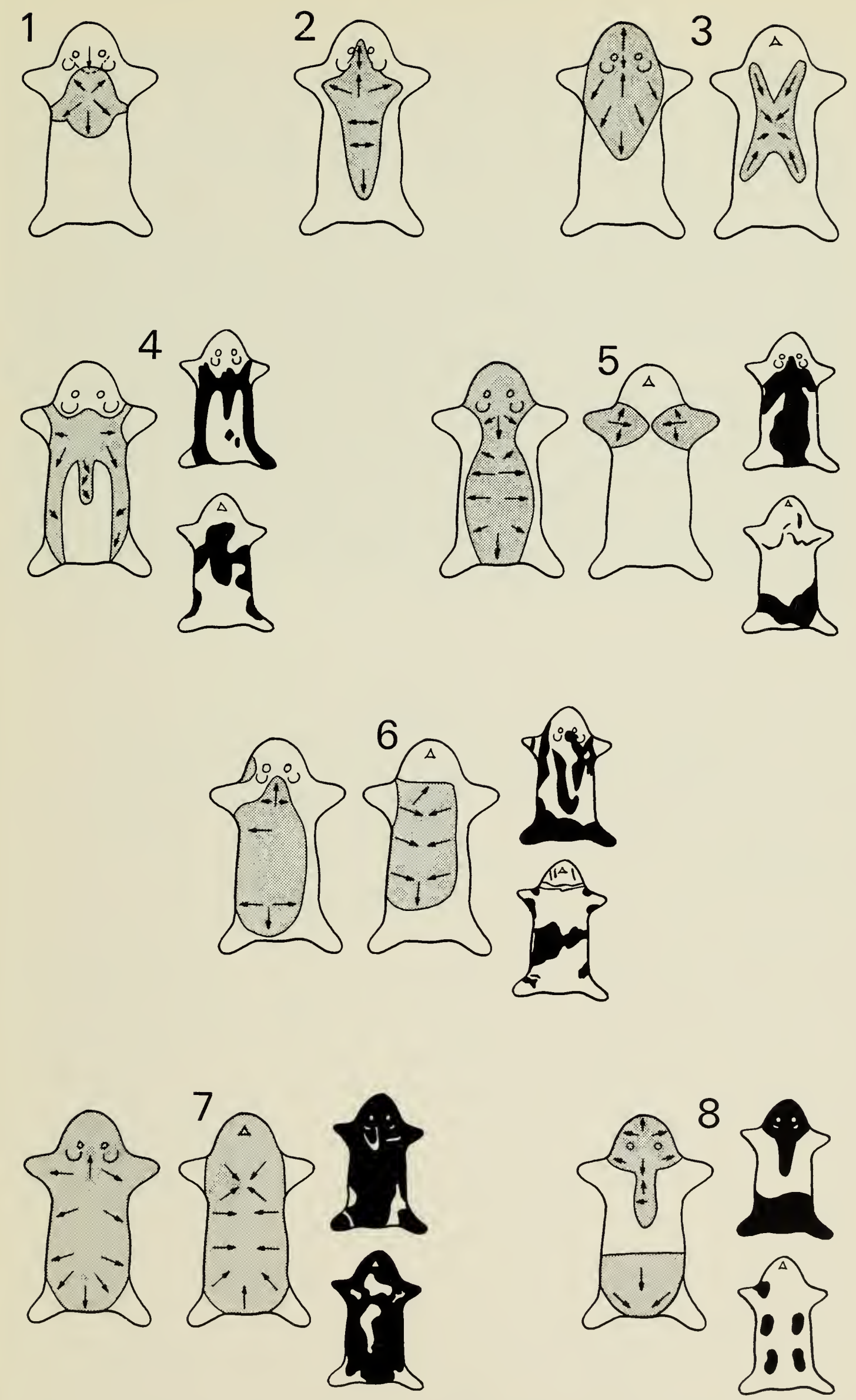

Fig. 21 Sequence of moult in late summer captured Ctenomys torquatus. The accompanying small figures in stages $4-8$ represent the internal deposition of melanin on the dorsal (upper small figure) and ventral (lower small figure) surfaces. 
conspicuous on the belly. Based on the extent of moult in animals collected in April, the hair replacement noted in February and March may represent the beginning of autumn moult, or simply may be regular hair replacement necessitated by attrition due to abrasion by gritty soil. Fifteen per cent of the Ctenomys torquatus obtained in February and March showed no indication of moult.

Tuco-tucos obtained in April were in the moult, and although a great deal of variation occurred, a basic pattern of hair replacement was discernible (Fig. 21). The initial growth centre develops mid-dorsally in an interscapular position and new growth proceeds anteriorly over the head. Posteriorly a narrow strip spreads along the mid-dorsal line and diagonally toward the sides of the thorax. Secondary centres may develop on the rump and mid-venter. Moult from the dorsum sweeps rapidly down the sides and cnto the venter, converging with the growth of new hair radiating from the ventral growth centre. Growth is first completed on the head, then on the belly and finally on the rump. Autumnal moult is not always completed in April as the individual taken in May, a female (AMNH 206547) obtained in Maldonado, showed extensive moult. 


\section{Concluding Remarks}

Prior to the arrival of the first European settlers in the 17th century, Uruguay was covered with a distinctive tall grass savannah fringed with thorn woodland (Wilhelmy and Rohmeder, 1963). Three centuries of intensive grazing by livestock on the great estancias and a general clearing of the uplands for other agricultural purposes combine to give modern-day Uruguay the appearance of disturbed tall-grass prairie. Upland woodland has largely disappeared and has been replaced by symmetrical plantings of eucalyptus which are notably poor in resident mammals. In general, the distribution and abundance of virtually all wild mammals has been influenced profoundly by the deterioration of the habitat.

In Uruguay rodents occur in the three basic habitats, i.e. woodlands, grasslands and limnic situations. Woodlands vary in plant composition, dimensions, and degree of association with waterways. Four of the species collected frequented woodland (Table 4) which varies from dense subtropical forest with a continuous canopy to open parkland-like growth. Only the arboreal mouse, Thomasomys oenax, is seemingly restricted to the dense subtropical forest.

\section{Table 4}

Habitat preferences of some Uruguayan rodents based on specimens and field observations obtained in 1962-63.

\begin{tabular}{|c|c|c|c|c|}
\hline \multirow[t]{2}{*}{ Species } & \multicolumn{2}{|c|}{ Woodland } & \multirow[t]{2}{*}{ Grassland } & \multirow{2}{*}{$\begin{array}{l}\text { Limnic } \\
\text { Situations }\end{array}$} \\
\hline & $\begin{array}{l}\text { Dense } \\
\text { (with canopy) }\end{array}$ & Open & & \\
\hline Oryzomys delticola & $\mathrm{X}$ & $\mathrm{X}$ & $\mathrm{X}$ & \\
\hline O. flavescens & & & $\mathrm{X}$ & $\mathrm{X}$ \\
\hline Thomasomys oenax & $\mathrm{X}$ & & & \\
\hline Akodon azarae & & $\mathrm{X}$ & $\mathrm{X}$ & $X$ \\
\hline A. obscurus & & & $\mathrm{X}$ & $\mathrm{X}$ \\
\hline Oxymycterus rufus & & & $\mathrm{X}$ & $\mathrm{X}$ \\
\hline Scapteromys tumidus & & & & $X$ \\
\hline Calomys laucha & & & $\mathrm{X}$ & \\
\hline Reithrodon physodes & & & $\mathrm{X}$ & \\
\hline $\begin{array}{l}\text { Holochilus } \\
\text { brasiliensis }\end{array}$ & & & & $\mathrm{X}$ \\
\hline H. magnus & & & & $\mathrm{X}$ \\
\hline Mus musculus & & & $\mathrm{X}$ & \\
\hline Cavia pamparum & & & $\mathrm{X}$ & $\mathrm{X}$ \\
\hline $\begin{array}{l}\text { Hydrochoerus } \\
\text { hydrochaeris }\end{array}$ & & $\mathrm{X}$ & $\mathrm{X}$ & $\mathrm{X}$ \\
\hline Myocaster coypus & & & & $\mathrm{X}$ \\
\hline Ctenomys torquatus & & & $\mathrm{X}$ & \\
\hline
\end{tabular}


Grasslands occupy the major portion of the land area and are inhabited by 11 species, three of which also occur in open woodland. Only Calomys laucha, Reithrodon physodes, Mus musculus and Ctenomys torquatus were found only in grassland.

Limnic habitat types included marshes, wet meadows and watercourses. Often where marshes and wet meadows are shielded from livestock by fences or dense growths of spiny caraguatá (Eryngium sp.) small mammals are locally numerous. Ten species characterized these habitats and three of them (Holochilus magnus, $H$. brasiliensis and Scapteromys tumidus) were taken nowhere else.

Hershkovitz (1963:43) has classified all South American mammals on the basis of their origin in a habitat type as reflected by their morphological adaptations and on the basis of their current habitat preferences. In Uruguay, among the species we collected, sylvan forms (species primarily adapted to living in forests) included arboreal cricetines. Pastoral forms (species primarily specialized for living in savannahs, scrublands, open swamp lands and marshes) include the caviomorph Cavia pamparum, the hystrichomorph Ctenomys torquatus, and some cricetines, e.g. Reithrodon physodes. 


\section{Literature Cited}

APLIN, O. V.

1894 Field-notes on the mammals of Uruguay. Proc. Zool. Soc. Lond., pp. 297-315.

AVILA-PIRES, F. D. DE

1960 Um novo gênero de roedor Sul-Americano (Rodentia-Cricetidae). Bol. Mus. Nac. Rio de Janeiro (Zool.), n.s. no. 220, pp. $1-6$.

BARLOW, J. C. AND J. CUELLO

1964 New records of Uruguayan birds. Condor, vol. 66, no. 6, pp. 516-517.

BERGEIRO, J. M.

1945 Clima del Uruguay. Montevideo [Urta y Curbelo], pp 1-24. BREWSTER, R. Q.

1953 Organic chemistry. 2nd ed., Englewood Cliffs, N.J., PrenticeHall Inc., pp. i-xii, 1-885.

BURMEISTER, H.

1879 Description physique de la République Argentine. vol. 3, Animaux vertébrés, Buenos Aires, pp. 1-555.

CABRERA, A. L.

1957 Catálogo de los mamíferos de América del Sur. 1. (Metatheria Unguiculata - Carnivora). Rev. Mus. Argent. Cienc. Nat. Bernardino Rivadavia. Zool. vol. 4, pp. i-iv, 1-307.

1961 Catálogo de los mamíferos de América del Sur. II. (SireniaPerissodactyla - Artiodactyla - Lagomorpha - Rodentia - Cetacea). Rev. Mus. Argent. Cienc. Nat. Bernardino Rivadavia. Zool. vol. 4, pp. v-xvi, xvii, 309-732.

CABRERA, A. L. AND J. YEPES

1960 Mamíferos Sud Americanos. Vida, costumbres y descripción. 2nd ed., Buenos Aires, Comp. Argentina de Editores, vol. 1, pp. 187, vol. 2, pp. 1-160.

DEVINCENZI, G. L.

1935 Mamíferos del Uruguay. An. Mus. Hist. Nat. Montev., vol. 2a, no. 4 (10), pp. 1-96.

FORNES, A. AND E. MASSOIA

1965 Small mammals (Marsupialia and Rodentia) collected in the locality of Miramar, Province of Buenos Aires. Physis, B. Aires 25, no. 69, pp. 99-108. [In Spanish, English summary]

HERSHKOVITZ, P.

1955 South American marsh rats, genus Holochilus, with a summary of sigmodont rodents. Fieldiana, Zool., vol. 37, pp. 639-687.

1959a Two new genera of South American rodents (Cricetinae). Proc. Biol. Soc. Wash., vol. 72, pp. 5-9.

1959b Nomenclature and taxonomy of the neotropical mammals described by Olfers, 1818. J. Mammal., vol. 40, no. 3, pp. 337-353.

1962 Evolution of neotropical cricetine rodents (Muridae) with special reference to the phyllotine group. Fieldiana, Zool., vol. 46 , pp. $1-524$.

1963 The recent mammals of South America. Proc. XVI Int. Congr. Zool. Wash., pp. 40-45.

1966 South American swamp and fossorial rats of the scapteromyine group (Cricetinae, Muridae) with comments on the glans penis in murid taxonomy. Z. Säugetierk, vol. 31, no. 2, pp. 81-149. 
HERTER, G.

1930 Florula Uruguayensis. Montevideo, pp. 1-191.

HORNER, B. E., J. M. TAYLOR AND H. A. PADYKULA

1964 Food habits and gastric morphology of the grasshopper mouse.

J. Mammal., vol. 45, no. 4, pp. 513-535.

JAMES, P. E.

1942 Latin America. New York, Odyssey Press, pp. 1-908.

LANGGUTH, A.

1963 Las especies Uruguayas del género Oryzomys (Rodentia, Cricetidae). Comun. Zool. Mus. Hist. Nat. Montev., vol. 7, no. 99, pp. 1-19.

LLANOS, A. C.

1964 Apreciacones de campo con motivo de una concentración de roedores en las provincias de Salta y Jujuy. Revta. Argent. Zoogeogr., vol. 4, pp. 51-57.

MASSOIA, E.

1961 Notas sobre los cricétidos de la Selva Marginal de Punta Lara (Mammalia, Rodentia). Publnes. Mus. Munic. Cienc. Nat. Tradic. Mar del Plata, vol. 1, no. 4, pp. 115-134.

1963 Sistemática, distribución geográfica y rasgos etoecológicos de Akodon (Deltamys) kempi (Rodentia-Cricetidae) - abstract. Physis, B. Aires, vol. 24, no. 67, p. 240.

MASSOIA, E. AND A. FORNES

1964 Notas sobre el género Scapteromys (Rodentia-Cricetidae). I. Sistemática, distribución, geográfica y rasgos etoecológicos de Scapteromys tumidus (Waterhouse). Physis, B. Aires, vol. 24, no. 68 , pp. 279-297.

MILLER, M. A.

1957 Burrows of the Sacramento Valley pocket gopher in flood-irrigated alfalfa fields. Hilgardia, vol. 26, no. 8, pp. 431-452.

PEARSON, O. P.

1959 Biology of the subterranean rodents Ctenomys, in Peru. Mems. Mus. Hist. Nat. "Javier Prado," vol. 9, pp. 1-56.

1967 La estuctura por edades y la dinámica reproductiva en una población de ratones de campo, Akodon azarae. Physis, B. Aires, vol. 27, no. 74, pp. 53-58.

PRADERI, R. AND H. LUZARDO

1958 Lista de mamíferos colectados en el Arroyo Tres Cruces Grande, Departmento de Artigas. Boln. Soc. Taguato, vol. 1, no. 1, pp. 26-32.

SANBORN, C. C.

1929 The land mammals of Uruguay. Fieldiana, Zool., vol. 17, no. 4, pp. $147-165$.

SIERRA DE SORIANO, B.

1960 Elementos consitutivos de una habitación de Myocastor coypus bonariensis (Geoffroy), ("nutria"). Revta. Fac. Hum. Cienc. Univ. Repub. Urug., vol. 18, pp. 257-276.

SIMPSON, G. G.

1945 The principles of classification and a classification of mammals.

Bull. Am. Mus. Nat. Hist., vol. 85, pp. i-xvi, 1-350.

TALICE, R. V. AND E. MOMIGLIANO

1954 Arquitectura y microclima de las tuqueros o maradas de Ctenomys torquatus. Archos. Soc. Biol. Montev., vol. 21, pp. 126-133. 
TALICE, R. V., E. MOMIGLIANO, S. LAFFITTE DE MOSERA AND J. C. LAGOMARSINO 1959 Investigaciones sobre Ctenomys torquatus un roedor autóctono del Uruguay. An. Fac. Med. Univ. Montev., vol. 44, no. 3-4, pp. $452-462$.

THOMAS, 0 .

1917 Some mammals from the delta of the Paraná. Ann. Mag. Nat. Hist., vol. 8a, ser. 20, pp. 95-100.

TWIGG, G. I.

1962 Notes on Holochilus sciureus in British Guiana. J. Mammal., vol. 43, no. 3, pp. 369-374.

VAZ FERREIRA, R.

1955 Viaje de William Toller a la Banda Oriental y Río de la Plata en 1715. Fac. Hum. y Cienc. Inst. Invest. Hist. y Lab. Zool., vol. 2, pp. i-xxix, 1-85.

WATERHOUSE, C. R.

1839 The zoology of the voyage of H.M.S. Beagle, under the command of Captain Fitzroy, R.N., during the years 1832 to 1836. Part 2, Mammalia, pp. i-ix, 1-97.

WILHELMY, H. AND W. ROHMEDER

1963 Die La Plata-Länder; Argentinien, Paraguay, Uruguay. Braunschweig, G. Westermann [1963], pp. 1-584.

XIMÉNEZ, A.

1965 Wiedomys pyrrhorhinos (Rodentia-Cricetidae) un nuevo mamífero para el Uruguay. Physis, B. Aires, vol. 25, no. 69, pp. 135-136. 


(c) $12^{4}$ 
LIBRARY

ROYAL ONTARIO MUSEUM 

